Article

\title{
Development and Application of a Novel QuEChERS Method for Monitoring of Tributyltin and Triphenyltin in Bottom Sediments of the Odra River Estuary, North Westernmost Part of Poland
}

\author{
Dawid Kucharski ${ }^{1}$, Przemysław Drzewicz ${ }^{2, * \mathbb{D}}$, Grzegorz Nałęcz-Jawecki ${ }^{3}$ (D), \\ Kamila Mianowicz ${ }^{4}$, Artur Skowronek ${ }^{2}$ (D) and Joanna Giebułtowicz ${ }^{1, *(D)}$ \\ 1 Department of Bioanalysis and Drugs Analysis, Faculty of Pharmacy, Medical University of Warsaw, \\ ul. Banacha 1, 02-097 Warszawa, Poland; dkucharski@wum.edu.pl \\ 2 Polish Geological Institute-National Research Institute, ul. Rakowiecka 4, 00-975 Warszawa, Poland; \\ asko@pgi.gov.pl \\ 3 Department of Environmental Health Sciences, Faculty of Pharmacy, Medical University of Warsaw, \\ ul. Banacha 1, 02-007 Warszawa, Poland; gnalecz@wum.edu.pl \\ 4 Institute of Marine and Environmental Sciences, University of Szczecin, Wały Chrobrego 1-2, \\ 70-500 Szczecin, Poland; Kamila.Mianowicz@usz.edu.pl \\ * Correspondence: przemyslaw.drzewicz@pgi.gov.pl (P.D.); joanna.giebultowicz@wum.edu.pl (J.G.); \\ Tel.: +48-22-459-2319 (P.D.); +48-572-0949 (J.G.); Fax: +48-22-849-5351 (P.D.); +48-22-572-0976 (J.G.)
}

Academic Editor: Tomasz Tuzimski

Received: 31 December 2019; Accepted: 24 January 2020; Published: 29 January 2020

\begin{abstract}
A Quick, Easy, Cheap, Effective, Rugged, and Safe (QuEChERS) extraction method combined with Liquid Chromatography-Tandem Mass Spectrometry (LC-MS/MS) for determination of organotin compounds (OTC) has been newly developed. The novel analytical method was validated and the quality of the results was tested by the use of certificate reference material of freshwater sediment BCR 646. The method was applied in determination of OTC concentration in real samples of bottom sediments collected from the Polish part of Odra River Estuary. The samples came from locations with different anthropogenic impact. Additionally, the extraction recovery of OTC and matrix effect on MS signal response was investigated based on those real environmental samples. It was found that organic compounds and anthropogenic contaminations present in bottom sediments may affect extraction efficiency of the organotin compounds (OTC) and change the matrix effect on MS signal response. The highest concentrations of tributyltin were found in bottom sediments collected from locations in vicinity of the Szczecin harbor and shipyards. The presence of triphenyltin above limit of detection (5 $\mathrm{ng} \mathrm{TPhT} / \mathrm{g}$ of sediment) was observed only in two samples and its concentration was several times lower compared to concentration of tributyltin (from $58 \mathrm{ng} / \mathrm{g}$ to $5263 \mathrm{ng} / \mathrm{g}$ ). In spite of the fact that, the application of TBT-based paints on hull of vessel entering EU ports has been banned by European Commission regulation No. 782/2003 since 2008, the OTC compounds are still present in bottom sediment and pose significant threat to the environment. This threat should be taken into account during dredging of waterways and other hydrotechnical works.
\end{abstract}

Keywords: tributyltin; triphenyltin; QuEChERS extraction; bottom sediments; Odra River estuary; LC-MS/MS

\section{Introduction}

Organic tin compounds (OTCs) have been widely used in industry, mainly for plastic manufacturing and in agriculture for crop protection [1]. However, OTCs have been mostly added 
to antifouling paints for protection of surface of ship hull against growth of microorganisms, plants, algae, or molluscs [2]. Because of OTCs high toxicity to environment, the usage of them was banned by International Marine Organization since 1st January 2003. Despite that, OTCs are still present in environment, especially in vicinity of shipyards, harbors or waterways [3]. Among organic tin compounds tributyltin (TBT) and triphenyltin (TPhT) are the most toxic to organisms. Those compounds attenuate oxidative phosphorylation in mitochondria [4], disrupt steroid homeostasis [5] and inhibit gene expression [6]. It was also reported that low concentrations of TBT and TPhT effect on imposex (the development of male characteristic in females) in many aquatic organisms [7].

TBT and TPhT are slightly soluble in water and thus their concentration levels in surface waters reported in literature are very low [8-10]. These compounds tend to accumulate in bottom sediments due to the ion-exchange and hydrophobic interactions with clay minerals and organic matter, respectively [11]. However, they may be released from the sediments during various biological processes or even seafaring during summertime [12]. Organotin compounds are very persistent in bottom sediments and pose risk for environment for a long time [13].

The gas chromatography with various detectors such as mass spectrometry, flame photometric detector, atomic emission detector, or, recently introduced, inductively couple plasma mass spectrometry have been widely used for detecting of organotin compounds (Table A2). In recent years inductively coupled plasma atomic emission spectroscopy analytical technique is also gained importance [14]. The most crucial step of OTC determination in sediments is the compounds extraction. Different non-polar solvents such as dichloromethane, hexane and toluene are used in these procedures. In order to improve efficiency, hydrochloric acid or organic acids such as boric acid are added to sample [15]. Lowering of sample $\mathrm{pH}$ decrease dissociation of OTC cations and reduce negative charge sites on surface of clay minerals and organic matter (mostly humic acids) present in the sediments. Moreover, addition of carboxylic acids reduces decomposition of OTC during sonication or microwave assisted extraction of the sample at elevated pressure and temperature (free radical scavenging). Besides, a complexing agent, for example, tropolone is added in order to improve the efficiency [16]. Trialkyl tin compounds are usually derivatized in situ to volatile tetraalkyl compounds by sodium tetraethylborate $\left(\mathrm{NaBEt}_{4}\right)$ prior GC analysis [17]. The major interference is elemental sulfur and sulfur containing compounds frequently present in the sediments [18]. Sulfur and sulfur compounds also undergo alkylation in reaction with $\mathrm{NaBEt}_{4}[19,20]$. Those compounds interfere in analysis of organic tin compounds by gas chromatography with mass spectrometry detector. Therefore, desulfurization step including the use of activated copper, oxidation by dimethyldioxirane (DMD) following by absorption by $\mathrm{Al}_{2} \mathrm{O}_{3}$ [19] is added to analytical procedure. Sulfur interferences may be removed by application of microwave assisted extraction at elevated temperature and pressure [21]. In the case of analysis of sediments, it is necessary to add more reagents during derivatization reaction in order to compensate for the consumption of reagents by side reactions with metal cations and other constituents in the matrices [22]. However, derivatisation step is not required for liquid chromatography (LC) allowing faster analytical procedures and eliminating a potential source of cross-contamination [13].

Extraction method introduced by Anastassiades [23] in 2002 and later validated by Lehotay [24] is one of the most promising user-friendly and high throughput extraction procedure that following green chemistry principles, involving reduced sample and organic solvents amounts used in the analysis. The method based on acetonitrile extraction/ partitioning of pesticides residues that covers a broad type of analytes, ranging from non-polar to very polar compounds. The method called QuEChERS from the Quick, Easy, Cheap, Effective, Rugged, and Safe is an effective sample preparation approach based on partitioning via salting-out extraction where an equilibrium between an aqueous and an organic layer (acetonitrile-ACN) is established [25]. The next step is dispersive solid-phase extraction step that involves further clean-up using several combinations of porous sorbents and salts to remove matrix interfering substances. QuEChERS approach was quickly found application in analysis of many other compounds in various biological and environmental matrices $[25,26]$. Nowadays, the method 
is adopted according to target analyte properties, matrix composition, equipment, and analytical techniques available in the laboratory.

The QuEChERS approach has been already used to extract tributyltin from Cunninghamella echinulate cultures [27]; however, the method was not validated. Despite of numerous analytical methods used for determination of organotin compounds in sediments $[13,28]$, the QuEChERS extraction combined with liquid chromatography mass spectrometry (LC-MS) for determination of tributyltin (TBT) and triphenyltin (TPhT) in bottom sediments was not developed and validate so far. Therefore, the aim of this work was to devise, develop and validate a QuEChERS sample preparation method for determination TBT and TPhT in bottom sediments from the Odra River Estuary (north-westernmost part of Poland) by the means of LC-MS/MS. The amount and combination of solvents and salts were optimized in terms of highest peak intensity of TBT and TPhT in extract from the sediments. The effect of sediments constituents on the ionization suppression or enhancement and extraction efficiency was also discussed. The optimized parameters of the method were tested and validated by the use of certificated reference material BCR646.

\section{Results and Discussion}

\subsection{Optimisation of the QuEChERS Extraction Procedure}

The method optimization was performed and following parameters were established: Effect of composition of extracting solutions, QuEChERS salts composition, d-SPE clean-up, extraction time, and agitation technique.

\subsubsection{Effect of Composition of Solutions and QuEChERS Salts}

The water and organic phase composition as well as salt addition for salting-out the analyte were optimized. The best salting-out of $\mathrm{ACN}$ is usually achieved by addition $\mathrm{MgSO}_{4}$ whereas addition of $\mathrm{NaCl}$ controls polarity of extraction solvents and thus allows to control the selectivity of the extraction [26]. However, the use of these salts can decrease detection limit and peaks intensity due to deposition of solid $\mathrm{NaCl}$ in MS source [29]. Therefore, the effect following three different QuEChERS salt compositions on extraction efficiency were investigated: 1) As was reported in the CEN Standard

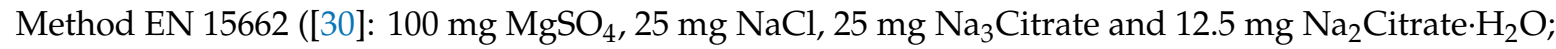
2) as was reported in AOAC Official Method [31]: $100 \mathrm{mg} \mathrm{MgSO}_{4}$ and $40 \mathrm{mg}$ sodium acetate (NaOAc) and 3) $100 \mathrm{mg}$ of ammonium acetate $\left(\mathrm{NH}_{4} \mathrm{OAc}\right)$. The effect of solvent composition on extraction efficiency was tested: MiliQ water, solution of $30 \mathrm{mM}$ potassium phosphate monobasic solution in MiliQ water $(\mathrm{pH}=7)$ as an aqueous phase and, as an organic phase, acetonitrile and solution of $5 \%$ formic acid in acetonitrile. Tributyltin and triphenyltin extractions were performed in all combinations of solvents with the use of three sets of QuEChERS salts (CEN Standard Method EN 15662, AOAC Official Method and $\mathrm{NH}_{4} \mathrm{OAc}$ ).

Organic solution: The results showed that the use of formic acid ( $5 \%$ in ACN) greatly increases peak intensity of TBT and TPhT. This is a result of adjustment of solution $\mathrm{pH}$ to around 5 . At $\mathrm{pH}$ below $\mathrm{pKa}=6.25$, tributyltin is predominantly present in cationic form TBT+; thus, desorption from sediments is favoured [32,33]. The same is for TPhT, which pKa $=5.2$ [32]. Moreover, surface of clay minerals is positively charged and humic acids are protonated in such conditions [32]. Therefore, there are no negative charge sites on surface sediment that may bond organotin cations.

Aqueous solution: $30 \mathrm{mM}$ potassium phosphate monobasic solution $(\mathrm{pH}=7)$ as aqueous phase was used as well. However, it was not observed any extraction efficiency improvement; thus for further analysis MiliQ water was used.

QuEChERS salts: The highest recoveries, both for TBT and TPhT, were observed in the presence of ammonium acetate. Contrary to sodium carboxylate salts, ammonium acetate salts easily vaporize and do not form solid deposits in electrospray ionisation (ESI) source of MS. Moreover, ammonium salts sometimes enhance ionization of analytes [34]. Therefore, ammonium acetate was used for further 
optimization of QuEChERS extraction procedure. The use of $\mathrm{NH}_{4} \mathrm{OAc}, 200 \mu \mathrm{L}$ MiliQ water and 5\% formic acid in acetonitrile resulted in the highest extraction recovery for TBT $63.5 \%(\mathrm{SD}=7.5 \%, n=5)$ and $62.4 \%$ for TPhT $(\mathrm{SD}=8.5 \%, n=5)$. The summary of the results of the investigations on the effect of various compositions of extracting solutions (Table 1) and composition of QuEChERS salts is presented in Figure 1.
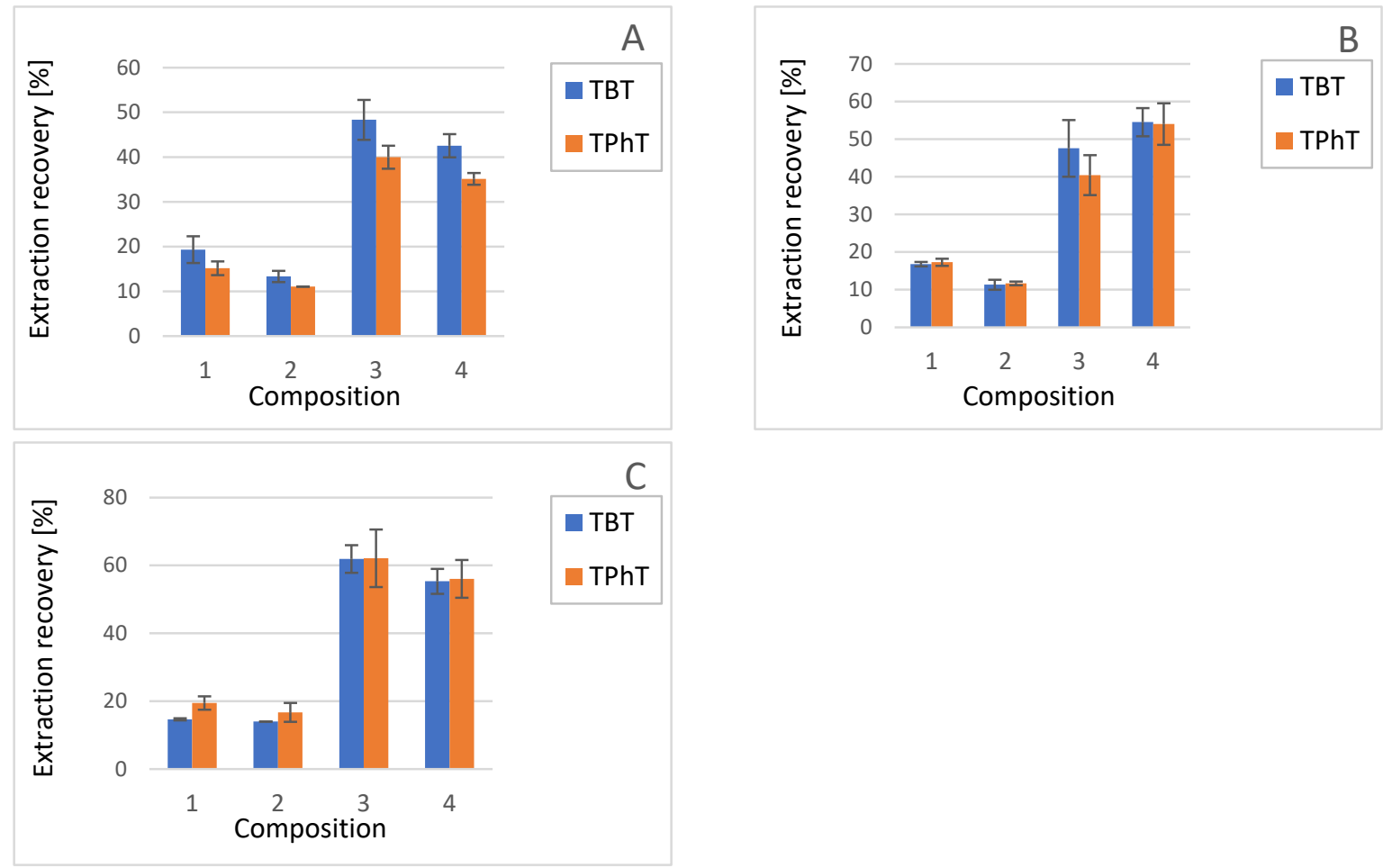

Figure 1. Extraction recovery of tributyltin (blue column) and triphenyltin (orange column) with the use of three QuEChERS salts A) $100 \mathrm{mg} \mathrm{MgSO}_{4}, 25 \mathrm{mg} \mathrm{NaCl}, 25 \mathrm{mg} \mathrm{Na}$ Citrate, and $12.5 \mathrm{mg}$ $\mathrm{Na}_{2}$ Citrate $\cdot \mathrm{H}_{2} \mathrm{O}$; B) $100 \mathrm{mg} \mathrm{MgSO}_{4}$ and $40 \mathrm{mg} \mathrm{NaOAc}$ and C) $100 \mathrm{mg} \mathrm{NH} \mathrm{NAC}_{4} \mathrm{OAs}$ QuEChERS salts. As an aqueous phase MiliQ water (composition 1 and 3) or monopotassium phosphate solution (composition 2 and 4) was used. As an organic phase pure acetonitrile (composition 1 and 2 ) or $5 \%$ formic acid in acetonitrile solution (composition 3 and 4) was used.

Table 1. The combinations of aqueous and organic solutions constituents used in the optimization procedure.

\begin{tabular}{cll}
\hline Composition Number & \multicolumn{1}{c}{ Aqueous Solution } & \multicolumn{1}{c}{ Organic Solution } \\
\hline 1 & MiliQ water & Acetonitrile \\
2 & $30 \mathrm{mM} \mathrm{KH}_{2} \mathrm{PO}_{4}$ solution in water $(\mathrm{pH}=7)$ & Acetonitrile \\
3 & $\mathrm{MiliQ} \mathrm{water}$ & Acetonitrile $+5 \%$ formic acid \\
4 & $30 \mathrm{mM} \mathrm{KH}_{2} \mathrm{PO}_{4}$ solution in water $(\mathrm{pH}=7)$ & Acetonitrile $+5 \%$ formic acid \\
\hline
\end{tabular}

\subsubsection{Effect of d-SPE Clean-Up}

High amounts of organic compounds in bottom sediments may cause faster stationary phase wearing off, sometimes suppress MS signal and affect validation parameters i.e.; lower limit of quantification (LLOQ), accuracy, and precision. Therefore, clean-up organic extract of the sediments before LC-MS/MS analyses is often recommended. In QuEChERS method acetonitrile extract of sample is clean-up by dispersive solid phase extraction (d-SPE). In d-SPE clean-up, octadecylsilane (C18) or primary-secondary amine (PSA) sorbents are frequently used for matrix interferences removal and for improving efficiency of chromatographic separation and MS signal performance [35]. In this study 
the application of PSA and C18 for clean-up of sediments extract did not bring any improvement in LC-MS analysis of TBT and TPhT. Extraction efficiency without clean-up was 73.1\% (SD = 4.9\%,n=5) for TBT and $65.1 \%(\mathrm{SD}=2.0 \%, n=5)$ for TPhT whereas, in the case of application of $100 \mathrm{mg} \mathrm{C} 18$, the efficiency dropped to $32.2 \%(\mathrm{SD}=4.1 \%, n=5)$ for TBT and $29.8 \%(\mathrm{SD}=2.7 \%, n=5)$ for TPhT (Figure 2$)$. Similar recoveries were obtained when $100 \mathrm{mg}$ PSA, $50 \mathrm{mg} \mathrm{C18}$, and their combination $50 \mathrm{mg}$ C18 and $50 \mathrm{mg}$ PSA was applied. It suggests that TBT and TPhT retained on PSA and C18 sorbents also as a complex with organic components of the matrix. Further study with other sorbent might be considered. However, in this case, additional clean-up step was not necessary. Clean-up by d-SPE did not improve performance of chromatographic separation and peak shape. No improvement of MS signal response, i.e.; signal to noise ratio and signal stability, was observed, even after more than 100 injections of samples with the same concentration of TBT and TPhT in the sediment. Hence, in further analysis of TBT and TPhT in sediments, the step of extract clean-up was excluded from the analytical method. As a result, the procedure of samples preparation became less laborious and time consuming.

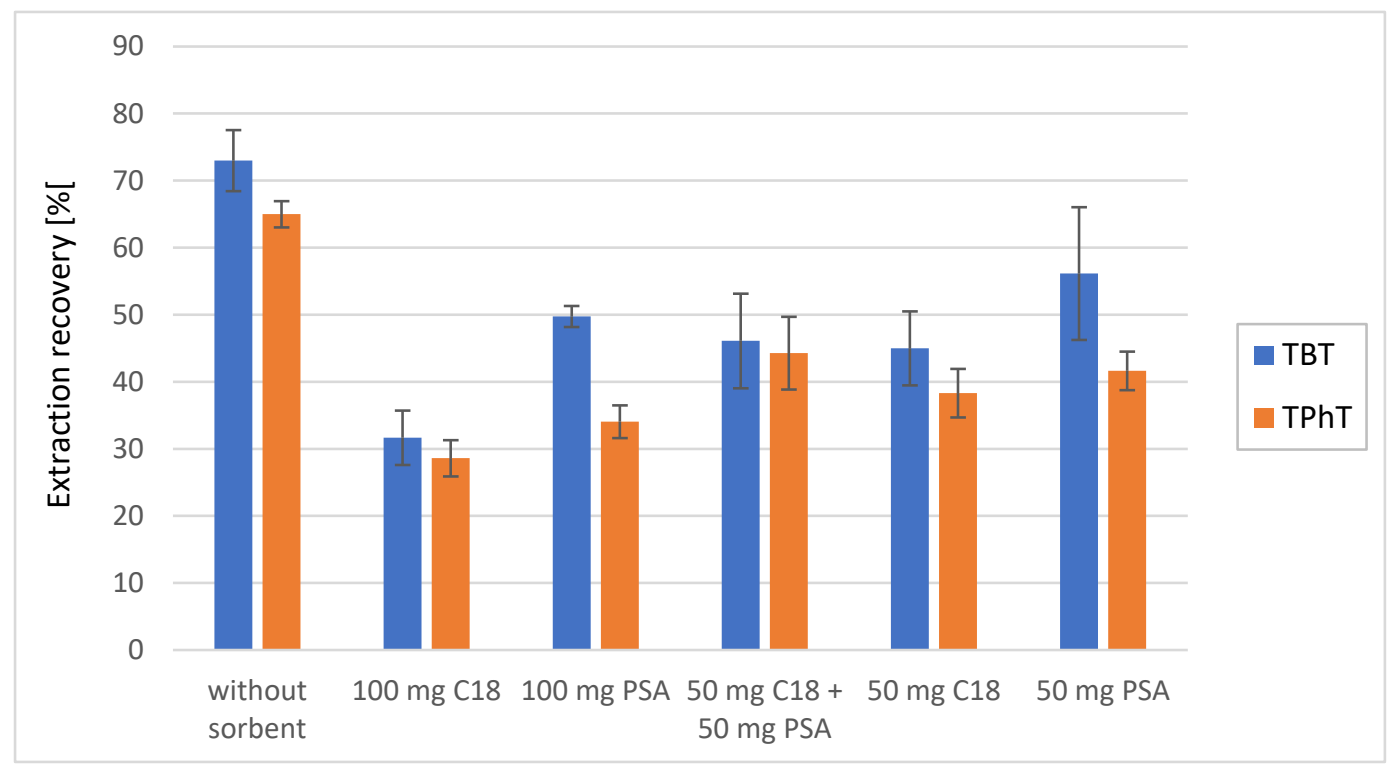

Figure 2. Extraction recovery of tributyltin (blue column) and triphenyltin (orange column) from sediments depending on using of different sorbents: C18 (octadecyl bound silica) and PSA (primary-secondary amine bound silica). As aqueous phase MiliQ water and as an organic phase 5\% formic acid in acetonitrile solution were used with ammonium buffer as QuEChERS salt.

\subsubsection{Effect of Extraction Time and Agitation Technique}

The time and simplicity of analysis are key factors in daily application of analytical methods. Therefore, extraction time and agitation technique in terms of extraction efficiency were optimized. The agitation of sample during extraction was carried out by vortexing with or without following sonication. The results show that the use of sonication greatly improve extraction efficiency what was reported previously [36]. Extraction efficiencies after 5 min of vortexing were $42.5 \%(\mathrm{SD}=1.9 \%$, $n=5)$ for TBT and $32.6 \%(\mathrm{SD}=1.2 \%, n=5)$ for TPhT whereas additional $5 \mathrm{~min}$ of sonication increased efficiencies to $69.3 \%(\mathrm{SD}=2.7 \%, n=5)$ for TBT and $55.7 \%(\mathrm{SD}=0.5 \%, n=5)$ for TPhT (Figure 3 ). Additionally, peaks intensities for $5 \mathrm{~min}$ of sonication and $5 \mathrm{~min}$ of vortexing were not statistically different in comparison to 15 min of vortexing alone ( $p=0.2838$ for TBT and $p=0.2021$ for TPhT). Therefore, application of combined vortexing and sonication may reduce extraction time significantly. It is worth to mention that the highest extraction efficiencies were obtained after 15 min of intensive vortexing following by additional sonication for $5 \mathrm{~min}$. The obtained extraction efficiency were $89.0 \%$ $(\mathrm{SD}=1.5 \%, n=5)$ for TBT and $85.6 \%(\mathrm{SD}=3.1 \%, n=5)$ for TPhT. However, extraction efficiency 
obtained after $5 \mathrm{~min}$ of vortexing and sonication is good compromise between desired duration of the extraction procedure and obtained extraction efficiency of organotin compounds.

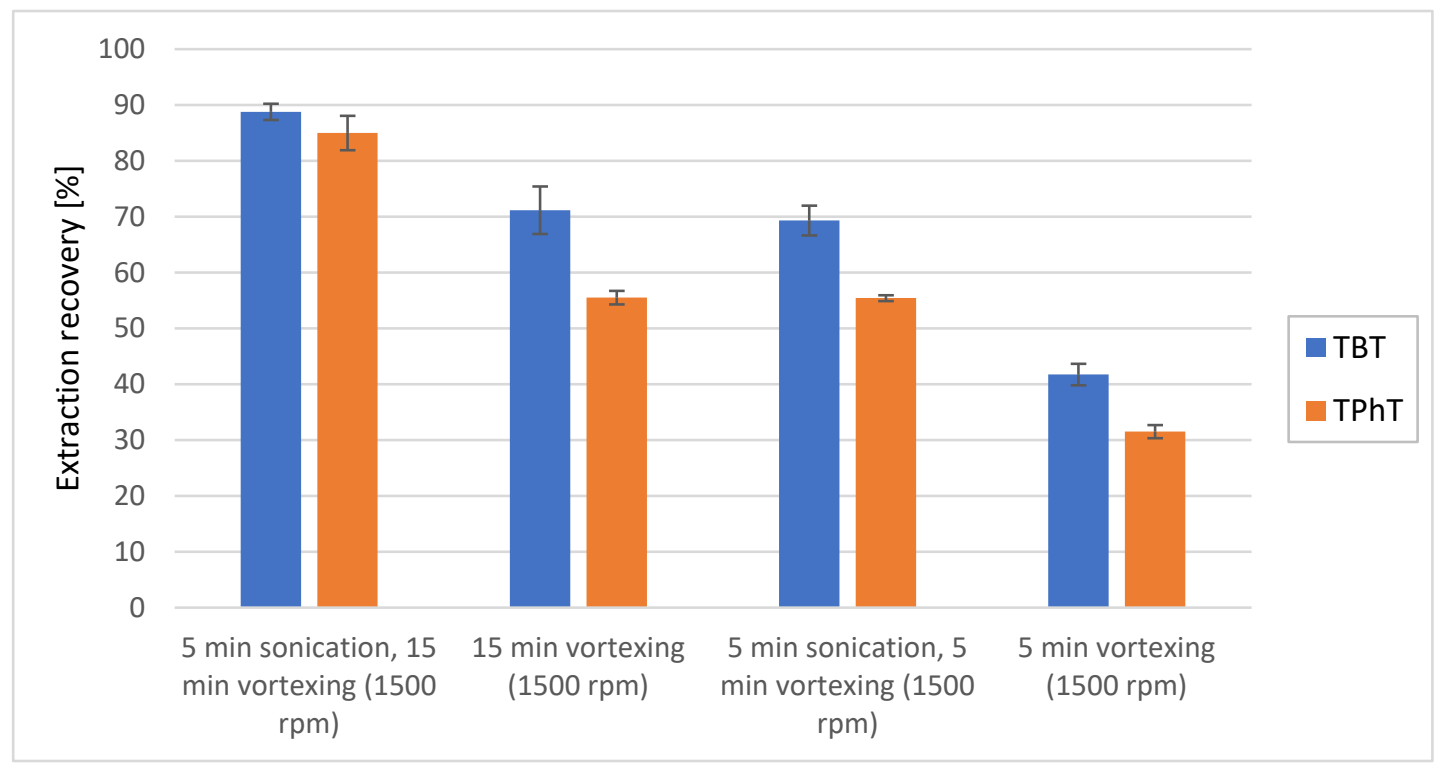

Figure 3. Extraction recovery of tributyltin (blue column) and triphenyltin (yellow column) from sediments depending on different extraction techniques and durations. As aqueous phase MiliQ water and as an organic phase $5 \%$ formic acid in acetonitrile solution were used with ammonium buffer as QuEChERS salt.

\subsection{Method Validation}

The method validation was performed and following parameters were established: analytical range (linearity), accuracy, precision, stability, selectivity and carry-over, matrix-effect, recovery according to EMA Guideline for Process Validation. Validation was carried out on sediments collected from the Odra River Estuary.

\subsubsection{Lower Limit of Quantification and Limit of Detection}

LLOQ defined as the lowest calibration standard on the calibration curve detected with appropriate precision and accuracy was $1 \mathrm{ng} / \mathrm{g}$ and $5 \mathrm{ng} / \mathrm{g}$ for TBT and TPhT respectively. LOD defined as the lowest analyte concentration that can be reliably detected was $0.6 \mathrm{ng} / \mathrm{g}$ and $2.4 \mathrm{ng} / \mathrm{g}$ for TBT and TPhT respectively.

\subsubsection{Analytical Range}

Analytical range (linearity) is the range where MS signal is proportional to analyte concentration in a sample without dilution. The response of MS instrument was tested for seven concentrations of the organotin compounds in MiliQ water $(n=6)$. The calibration curve obtained by application of weighted linear regression (1/x) was linear in the range $1-4000 \mathrm{ng} / \mathrm{g}$ for TBT and $5-4000 \mathrm{ng} / \mathrm{g}$ for TPhT. The values of regression parameters for the curve, described by the equation: $y=a x+b$, were calculated as: $\mathrm{a}=0.00073(\mathrm{SD}=0.00021, n=6), \mathrm{b}=0.0052(\mathrm{SD}=0.0121, n=6)$ and $\mathrm{R}^{2}=0.992$ for TBT and $\mathrm{a}=0.00157(\mathrm{SD}=0.00005, n=6), \mathrm{b}=-0.012(\mathrm{SD}=0.028, n=6)$, and $\mathrm{R}^{2}=0.994$ for TPhT. All regression parameters were statistically significant $(p<0.05)$.

\subsubsection{Accuracy and Precision}

Accuracy and precisions are two the most important elements of a chromatographic analytical method. Accuracy is defined as a measure of closeness of the experimental result of analyte 
determination to the real amount of the substance in the real matrix. The precision of a method is a measure of how variable are the experimental results when the method were applied under well-controlled conditions [37]. In the validation process the accuracy and precision for LLOQ and QC samples within one day $(n=5)$ and between runs $(n=15)$ met the acceptance criteria of Medicines Agency Guideline for Process Validation (Table 2). Chromatograms of control samples of sediments, LLOQ and selected sediment sample are presented in Appendix (Figure A1). The signal to noise ratio for LLOQ was 5.3 and 7.2 for TBT and TPhT, respectively.

Table 2. Precision and accuracy data for tributyltin (TBT) and triphenyltin (TPhT).

\begin{tabular}{|c|c|c|c|c|}
\hline \multicolumn{5}{|c|}{ TBT } \\
\hline Nominal Concentration (ng/g) & 1 & 3 & 2500 & 4000 \\
\hline Within-run precision $(\%)(n=5)$ & $1.5-2.7^{\mathrm{a}}$ & $2.8-3.9$ & $5.3-6.2$ & $2.1-3.0$ \\
\hline Within-run accuracy $(\%)(n=5)$ & $95-102^{b}$ & 85-104 & 98-106 & 98-101 \\
\hline Between-run precision $(\%)(n=15)$ & $1.9^{\mathrm{a}}$ & 3.5 & 5.6 & 2.6 \\
\hline Between-run accuracy $(\%)(n=15)$ & $102^{b}$ & 99 & 103 & 100 \\
\hline \multicolumn{5}{|c|}{ TPhT } \\
\hline Nominal concentration (ng/g) & 5 & 15 & 2500 & 4000 \\
\hline Within-run precision $(\%)(n=5)$ & $2.2-6.6^{\mathrm{a}}$ & $3.2-9.3$ & $4.0-7.6$ & $3.7-9.5$ \\
\hline Within-run accuracy $(\%)(n=5)$ & $108-117^{b}$ & $91-97$ & $97-102$ & 100-104 \\
\hline Between-run precision $(\%)(n=15)$ & $4.3^{\mathrm{a}}$ & 6.8 & 5.7 & 5.7 \\
\hline Between-run accuracy $(\%)(n=15)$ & $112^{b}$ & 95 & 101 & 102 \\
\hline
\end{tabular}

Accepted precision: $\leq 15 \%\left({ }^{a} \leq 20 \%\right)$. Accepted accuracy: $85-115 \%$ ( $\left.{ }^{b} 80-120 \%\right)$.

\subsubsection{Selectivity and Carry-Over}

Selectivity is a measure of the extent to which the method can determine a particular analyte in the matrix without any interference from matrix components. It was established as a ratio of peak area in the blank sample of bottom sediment (without OTC compound) at retention time corresponding to retention time of the analyte to peak area corresponding to concentration of lower limit of analyte quantification. Established selectivity was $6.1 \%(\mathrm{SD}=3.3 \%, n=6)$ for tributyltin, 3.8\% $(\mathrm{SD}=2.6 \%, n=6)$ for triphenyltin and $1.2 \%(\mathrm{SD}=0.2 \%, n=6)$ for tributyltin $\mathrm{d}-27$. Carry-over caused by contamination from preceding analyses is major problem that may affect the accuracy and precision of the analytical method. It was established as a ratio of peak area corresponding to the analyte concentration in the blank sample ( $A_{\text {blank sample }}$ ) to the peak area corresponding to concentration of lower limit of analyte quantification (ALLQ) (Equation (1))

$$
\text { Carry }- \text { over }=\left[A_{\text {blank sample }} / A_{L L O Q}\right] \times 100 \%,
$$

The calculated carry-over was $1.21 \%(\mathrm{SD}=0.35 \%, n=6)$ for tributyltin, $1.14 \%(\mathrm{SD}=0,53 \%, n=6)$ for triphenyltin and $0.3 \%(\mathrm{SD}=0.1 \%, n=6)$ for tributyltin $\mathrm{d}-27$. All results met acceptance criteria $(<20 \%$ for analyte and $<5 \%$ for internal standard) of EMA Guideline for Process Validation.

\subsubsection{Stability}

Stability is usually described as the degree of decomposition of analyte in matrix and stock solution under specific storage conditions after certain time. Stability of the analyte affects the trueness and precision of the analytical procedure. Stability of analytes was determined as a comparison of concentration of fortified blank samples of sediment to reference sample. The freeze/thaw stability was investigated in fortified sediments after 3 cycles of freezing and thawing. Short-term stability was established after $4 \mathrm{~h}$ storage of the solution at room temperature. Long term stability was established after 30 days storage of working solutions in $-25^{\circ} \mathrm{C}$. Stability in the LC autosampler was established after $24 \mathrm{~h}$ and $48 \mathrm{~h}$. The stability tests were repeated 5 times. Stability of stock solutions $(10 \mu \mathrm{g} / \mathrm{mL})$ 
after 30 days storage in $-25{ }^{\circ} \mathrm{C}$ was $106 \%$ for TBT, $113 \%$ for TPhT and $85 \%$ for TBT-d27. All results met the acceptance criteria in range $85-115 \%$ of EMA Guideline for Process Validation (Table 3).

Table 3. Parameters of stability tests for tributyltin (TBT) and triphenyltin (TPhT) in sediments.

\begin{tabular}{|c|c|c|c|c|c|}
\hline & & \multicolumn{2}{|c|}{ TBT } & \multicolumn{2}{|c|}{ TPhT } \\
\hline & & $3 \mathrm{ng} / \mathrm{g}$ & $4000 \mathrm{ng} / \mathrm{g}$ & $15 \mathrm{ng} / \mathrm{g}$ & $4000 \mathrm{ng} / \mathrm{g}$ \\
\hline Long-term stability & & 114 & 113 & 113 & 112 \\
\hline Short-term stability & & 97 & 104 & 92 & 95 \\
\hline Freeze/thaw stability & & 114 & 104 & 90 & 91 \\
\hline \multirow{2}{*}{ Stability in autosampler } & After $24 \mathrm{~h}$ & 99 & 98 & 110 & 102 \\
\hline & After $48 \mathrm{~h}$ & 100 & 99 & 112 & 105 \\
\hline
\end{tabular}

Accepted precision: $\leq 15 \%$. Accepted accuracy: $85-115 \%$.

\subsubsection{Estimation of Trueness}

Trueness is the closeness of agreement between a test result and the accepted reference value of the property being measured. Trueness is stated quantitatively in terms of "bias", with smaller bias indicating greater trueness. Bias is typically determined by comparing the response of the method to a reference material with the known value assigned to the material [38]. Estimation of trueness was carried out by the use of certificate reference material (CRM) of freshwater sediments $B C^{\circledR}$ 646; the certificated concentration of TBT and TPhT was $480 \mathrm{n} / \mathrm{g}$ and $29 \mathrm{ng} / \mathrm{g}$. CRMs are traceable to international standards with a known uncertainty; thus, it can be used to assess simultaneously laboratory and method bias, assuming that there is no matrix mismatch $[39,40]$. Significance testing of the bias that took into account uncertainty of certificated value was performed. According to ISO Guide 33 [41], the expend uncertainty of the difference between certificated and measured value $U_{\Delta}$ with coverage factor $\mathrm{k}=2$, corresponding to a level of confidence 95\%, is obtained by (Equation (2)):

$$
u_{\Delta}=k \cdot \sqrt{u_{r e f}^{2}+\frac{S_{m}^{2}}{n}},
$$

where: $u_{r e f}$ is the uncertainty of the reference value taken from the certificate $(40 \mathrm{n} / \mathrm{g}$ for TBT and $5.5 \mathrm{ng} / \mathrm{g}$ for TPhT); $s_{m}$ is a standard deviation calculated from the measured values; $n$ is a number of repeated measurements, $(n=6)$.

The difference between the certified reference value (taken from the certificate $-480 \mathrm{n} / \mathrm{g}$ for TBT and $29 \mathrm{ng} / \mathrm{g}$ for TPhT) and the mean measured value obtained by combined QuEChERS and LC-MS methods was $\Delta_{\mathrm{TBT}}=30 \mathrm{ng} / \mathrm{g}$ for TBT and $\Delta_{\mathrm{TPhT}}=1 \mathrm{ng} / \mathrm{g}$ for TPhT. The difference is within $U_{\Delta}$, thus the measured concentrations is compatible with reference concentrations.

\subsubsection{The Matrix Effect}

Environmental matrix components often presented in non-clean-up extracts may affect ionization of analyte in MS. However there are many publications the purification step is not needed in extraction procedure [42]. Moreover, in this study, the results of method optimization have shown that commonly used sorbents for clean-up were not suitable for extract containing TBT and TPhT. Thus, it is very important to evaluate the matrix effect on signal response of the analyte. The presence of matrix effect results in poor analytical accuracy, linearity, and reproducibility, however, in the case of MS detector, selection of appropriate isotope labelled internal standard may control it [43]. In the study, deuterated TBT (TBT-d27) was used as an internal standard. Matrix effect was investigated in 10 samples of bottom sediments collected from the Odra River Estuary which were sieved to grain size below $0.6 \mathrm{~mm}$. Detailed characteristics of the sediments are presented in Appendix (Table A1).

The absolute matrix effect $\left(\mathrm{ME}_{\mathrm{A}}\right)$ is described as an increase or decrease of MS signal response of analyte in the presence of environmental matrix in relation to the response of the same concentration 
of analyte in pure water solution (without environmental matrix). $\mathrm{ME}_{\mathrm{A}}$ was in range 58-92\% for TBT $(\bar{x}=76.1 \%, \mathrm{SD}=9.4 \%)$ and $58-92 \%(\bar{x}=72.3 \%, \mathrm{SD}=10.4 \%)$ for TPhT. The results of Spearman's correlation analysis suggest that compounds presents in anthropogenically impacted bottom sediments and granulometry may suppress the ionization of TBT in MS. Positive correlation was observed for polycyclic aromatic hydrocarbons $(\mathrm{PAH})(\mathrm{r}=0.6930, p=0.0263)$, heavy metals content $(\mathrm{r}=0.6846$, $p=0.0288)$, silt fraction $(\mathrm{r}=0.7599, p=0.1076)$ and negative correlation for sand fraction $(\mathrm{r}=-0.7454$, $p=0.0133$ ). In the case of TPhT, the ionization suppression was positively correlated with content of total organic carbon $(\mathrm{r}=0.6626, p=0.0368)$, acid volatile sulfur $(\mathrm{r}=0.7112, p=0.0211), \mathrm{PAH}(\mathrm{r}=0.8262$, $p=0.0032)$ and silt fraction $(\mathrm{r}=0.6524, p=0.0409)$, and negatively correlated with sand fraction $(\mathrm{r}=-0.6443, p=0.0443)$. It confirms that anthropogenic contaminations result in ionization suppression during MS analysis of organotin compounds. Other correlations were statistically insignificant.

In order to better visualize all results and evaluate the relationships between the values of matrix effect and parameters presented in Table A1, principal component analysis (PCA) was performed (Figures 4 and 5). PCA reduces the large number of parameters to interrelated variables and enabled to present data variation in a new coordinate system. The combination of principal components that adequately demonstrates differences between them was presented. Samples with the greatest $\mathrm{ME}_{\mathrm{A}}$ value were marked by green dot. In the case of tributyltin (Figure 4), high content of heavy metals and clay fraction as well as low total organic carbon content, nitrogen content and sand fraction was associated with higher analytical signal suppression. For triphenyltin (Figure 5), high content of polycyclic aromatic hydrocarbons and slightly acid volatile sulfur content affected the matrix effect. It was also observed impact of silt fraction on decrease of analytical signal suppression. The results of PCA likely indicated that presence of petroleum oil compounds may affect nebulization and ionization of organotin compounds in ESI source of the mass spectrometer. For example, in the sample of sediment collected from port of Szczecin the concentration of $\mathrm{PAH}$ was $9828 \mathrm{mg} / \mathrm{kg}$ that resulted in $\mathrm{ME}_{\mathrm{A}}=58 \%$ (Table A1). Such high concentration of PAH indicates high pollution of oil compounds. Additionally, formation of charge neutral cluster or ion-pair with high molecular weight aromatic compounds or/and containing heteroatoms (nitrogen) is a plausible explanation of high $\mathrm{ME}_{\mathrm{A}}$ for this sample. Therefore, improvement of versatility of the analytical method will be a subject of further investigation.

Additionally, the mineral content of the bottom sediments is also important in MS determination of organotin compounds. Minerals may facilitate adsorption of organic compounds due to hydrophobic or/and ionic interactions. Especially, clay minerals (e.g.; kaolinite, montmorillonite) due to cationic exchange properties (at pH around 7) may adsorb not only organotin cations but also other compounds, especially containing nitrogen (amines, polycyclic aromatic nitrogen containing hydrocarbons and alkyl pyridinium surfactants). The clay minerals are predominant in fraction below $0.063 \mathrm{~mm}$. The absolute matrix effect was established for 5 different samples of bottom sediments before and after sieving through $0.063 \mathrm{~mm}$ sieve. Decrease of $\mathrm{ME}_{\mathrm{A}}$ level was observed both for tributyltin and triphenyltin in the samples of sediments after sieving. In the case of $\mathrm{TBT}, \mathrm{ME}_{\mathrm{A}}$ level decreased from $77.2 \pm 7.5 \%$ to $65.6 \pm 2.2 \%(p=0.0389)$ and from $74.4 \pm 7.1 \%$ to $65.6 \pm 1.5 \%$ for TPhT $(p=0.0103)$. Although the amount of clay mineral fraction in bottom sediments did not have any direct effect on LC-MS method, the amount of interfering compounds increase with the increase of this fraction. This should be taken into account when the QuEChERS extraction method will be tailored to the analysis of bottom sediments from other part of world.

The absence of the $\mathrm{ME}_{\mathrm{A}}$ is only desirable because suppression or enhancement of the signal does not influence quantification. But, the absence of the relative matrix effect $\left(\mathrm{ME}_{\mathrm{R}}\right)$ is crucial to obtaining reliable results and is mandatory during method validation. In the study the relative matrix were $4 \%$ for tributyltin and 5\% for triphenyltin and met acceptance criteria $(<15 \%)$. Although it was observed suppression or enhancement of the analytical signal for the individual sediment, the results of relative matrix effect show that the method can be considered as fully reproducible for analysis of TBT and TPhT in bottom sediments. 


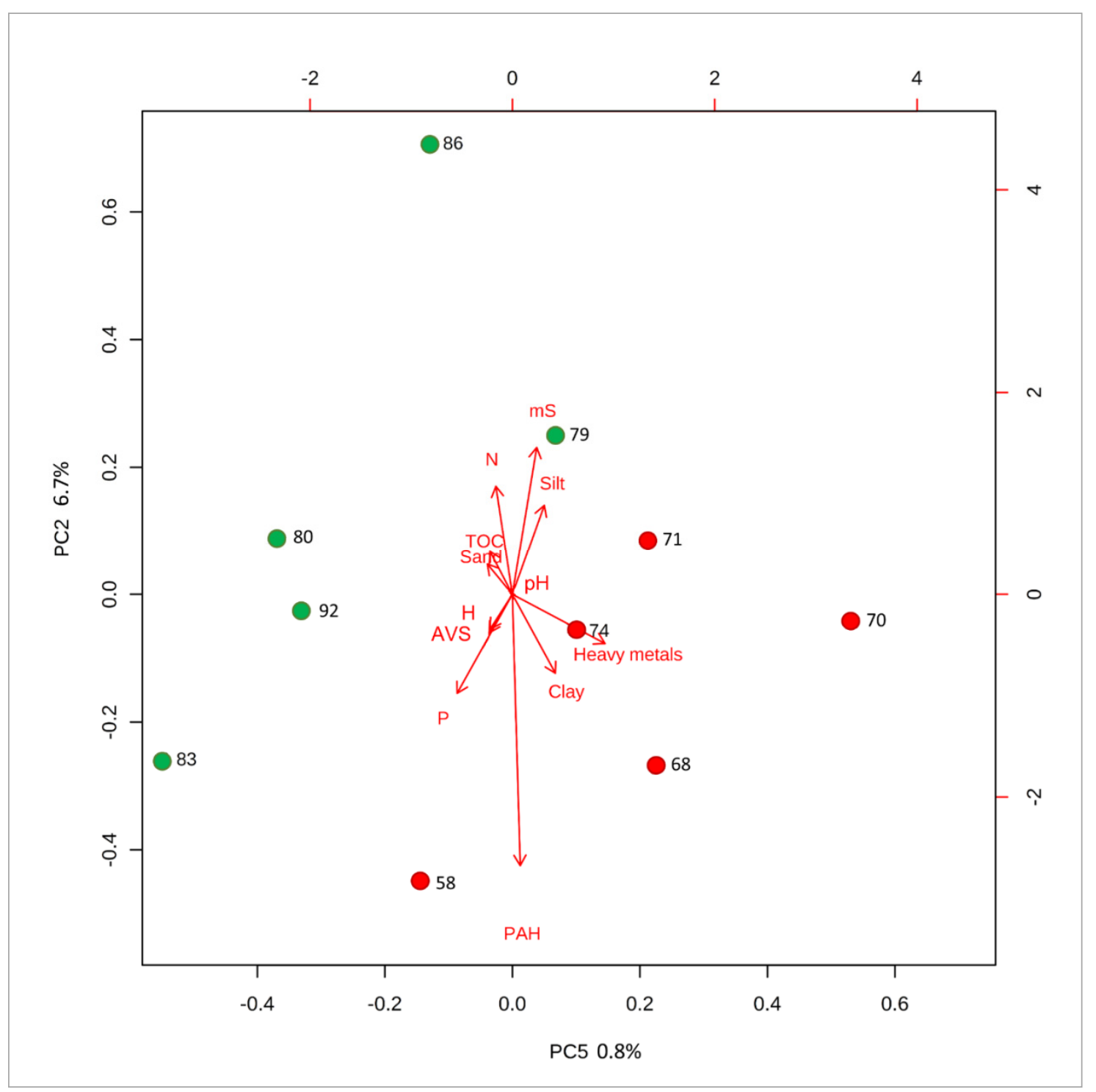

Figure 4. Principal component analysis (PCA)—distribution of the $\mathrm{ME}_{\mathrm{A}}$ of $\mathrm{TBT}$ for a different sediments on a biplot (principal component 2 vs principal component 4). The sample labels refer to $\mathrm{ME}_{\mathrm{A}}$ value. The biplot arrows point in the direction of increasing values for that variable. The length of the arrows approximates the variance of the variables, whereas the angles between them- approximate their intercorrelations. The variables are $\mathrm{pH}$ value, conductivity $(\mathrm{mS})$, total organic carbon $(\%)$, total nitrogen content $(\%)$, total hydrogen content $(\%)$, acid volatile sulfur $(\%)$, total phosphorus content $(\%)$, sum of heavy metals $(\mathrm{mg} / \mathrm{kg})$, polycyclic aromatic hydrocarbons $(\mu \mathrm{g} / \mathrm{kg})$, clay content $(\%)$, silt content $(\%)$, and sand content $(\%)$. 


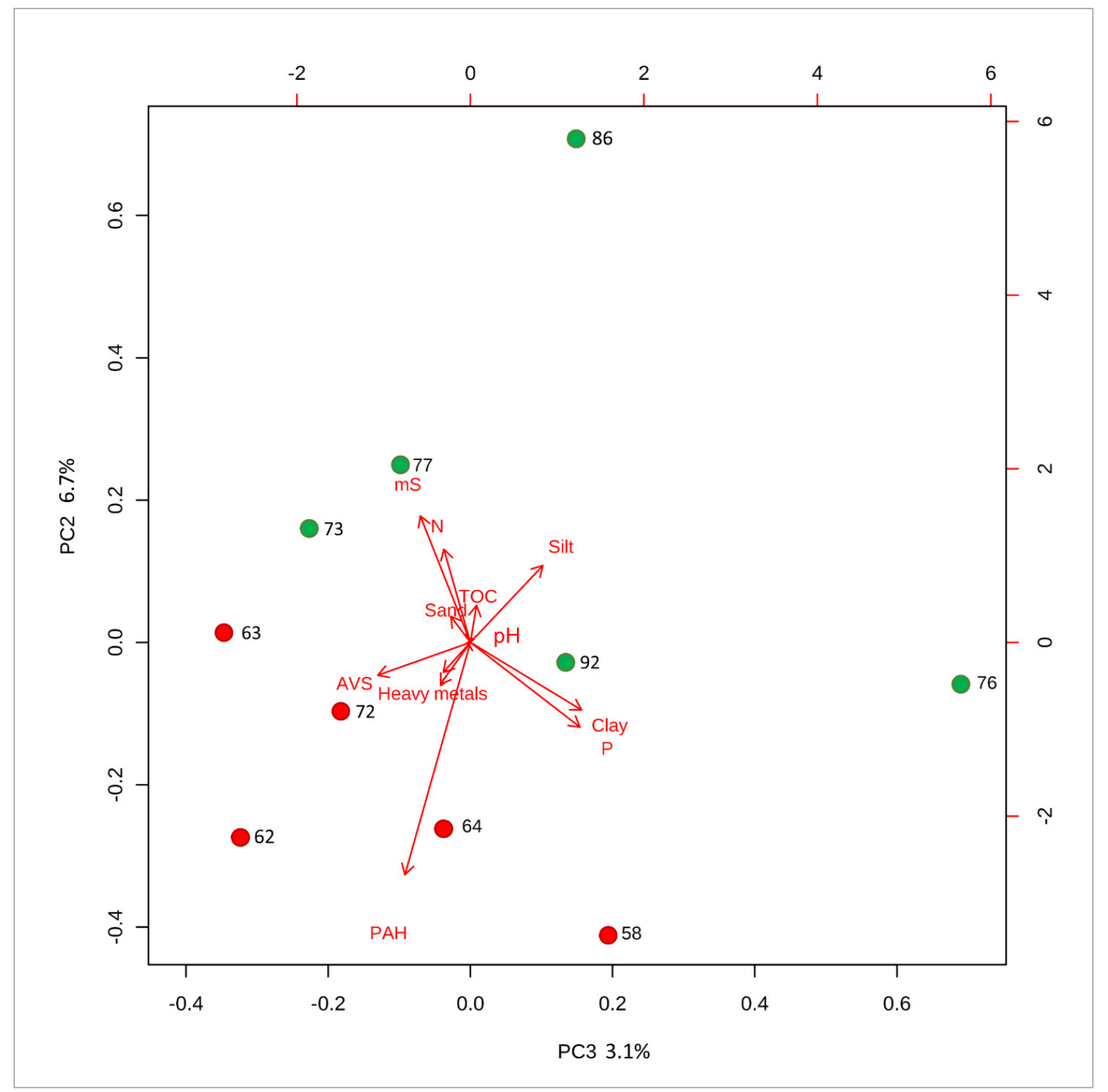

Figure 5. Principal component analysis (PCA)—distribution of the $\mathrm{ME}_{\mathrm{A}}$ of $\mathrm{TPhT}$ for a different sediments on a biplot (principal component 3 vs principal component 4 ). The sample names refers to $\mathrm{ME}_{\mathrm{A}}$. The biplot arrows point in the direction of increasing values for that variable. The length of the arrows approximates the variance of the variables, whereas the angles between them-approximate their correlations with $\mathrm{pH}$ value, conductivity $(\mathrm{mS})$, total organic carbon $(\%)$, total nitrogen content $(\%)$, total hydrogen content $(\%)$, acid volatile sulfur (\%), total phosphorus content $(\%)$, sum of heavy metals $(\mathrm{mg} / \mathrm{kg})$, polycyclic aromatic hydrocarbons $(\mu \mathrm{g} / \mathrm{kg})$, clay content $(\%)$, silt content $(\%)$, and sand content $(\%)$.

\subsubsection{Extraction Recovery}

The extraction recovery for tributyltin was $85-106 \%(\bar{x}=93.2 \%, \mathrm{SD}=6.1 \%)$. Thus, almost all TBT was recovered from sediments. It was observed positive correlation with sand $(\mathrm{r}=0.7356, p=0.0153)$ and negative with silt fraction $(\mathrm{r}=-0.7256, p=0.0175)$. The extraction recovery for TPhT was $85-99 \%$ $(\bar{x}=90.5 \%, \mathrm{SD}=4.2 \%)$. Thus, almost all TPhT was recovered from sediments. RE was positively correlated with sand $(\mathrm{r}=0.7112, p=0.0211)$ and negatively correlated with PAH content $(\mathrm{r}=-0.7896$, $p=0.0066)$, and silt fraction $(\mathrm{r}=-0.7226, p=0.0182)$. The further statistical analyses were not conducted due to satisfactory efficiency of the validated method. 


\subsection{Application of the Method to the Real Environmental Samples}

The earlier studies have shown the presence of elevate concentration of the organotin compounds, especially tributyltin and triphenyltin, in bottom sediments from the southern coast of the Baltic Sea. The concentrations detected in sediments collected from the Gdansk Gulf ranged from $2 \mathrm{ng} / \mathrm{TBT} / \mathrm{g}$ of sediment to almost 38,900 ng/TBT/g of sediment collected nearby Gdansk Shipyard. In comparison, in this study, the concentrations of TBT in sediments from the Szczecin Lagoon were from $5 \mathrm{ng} / \mathrm{g}$ to $280 \mathrm{ng} / \mathrm{g}$. In the case of TPhT the highest concentration of triphenyltin was $961 \mathrm{ng} / \mathrm{g}$ of sediment from Gdansk shipyard [44], whereas in this study the concentrations of the compound determined in the most samples collected from the Odra River Estuary were below limit of detection.

In present study, developed combined QuEChERS and LC-MS method was applied to analysis of TBT and TPhT in below $0.063 \mathrm{~mm}$ fraction of bottom sediments from the Odra River Estuary (Figure 6). High concentration of TOC suggests that the sediments may accumulate large amounts of organotin compounds. High concentration of heavy metals found in those samples indicated that Odra River Estuary have been strongly impacted by industrial activity.
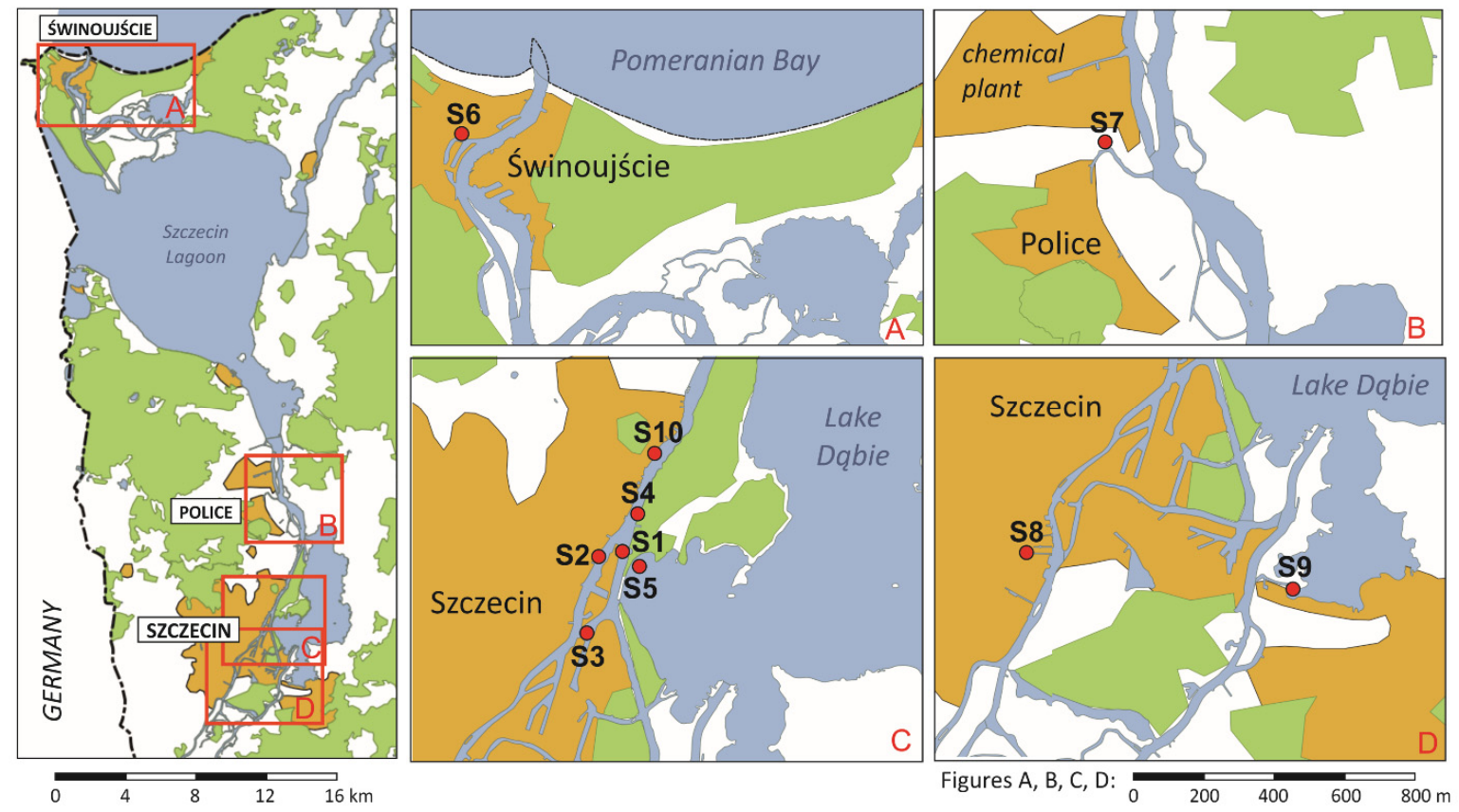

Figure 6. The map of points where samples of sediments were collected in the area of Świna River Estuary (A) and Larpia River-Police (B), Szczecin Harbor and Lake Dabie (C and D). Geographic coordinates of sampling locations were given in Table 6.

The highest concentrations of TBT were found in bottom sediment from the region of West Odra River (5263 ng/g), Gunica River (3884 ng/g), and Szczecin Shipyard (3296 ng/g) (Table 4). These are highly populated areas with developed maritime and shipyard industry. It corroborates the results of preceding studies that linked high concentration of TBT with maritime industry activity [44]. In the case of TPhT, the concentrations above LLOQ were detected only in bottom sediments collected nearby grain elevator "Ewa", grain port quay $(90 \mathrm{ng} / \mathrm{g})$ and West Odra River $(9 \mathrm{ng} / \mathrm{g})$. TPhT was used as a fungicide in crop protection till 2002 (it was phase-out by Commission Decision of 20 June 2002, 2002/479/EC). 
Table 4. Concentration of TBT and TPhT in below $0.063 \mathrm{~mm}$ fraction of bottom sediments, physicochemical characteristic of the sediments (conductivity and pH of MiliQ water extract, total organic carbon content (TOC), total nitrogen content (N), hydrogen content (H), acid volatile sulfur (AVS), phosphorus content (P), heavy metals (arsenic, barium, cadmium, cobalt, chromium, copper, iron, molybdenum, nickel, mercury, lead, tin, zinc), sum of 16 priority polycyclic aromatic hydrocarbons $(\mathrm{PAH}))$ and grain size distribution.

\begin{tabular}{|c|c|c|c|c|c|c|c|c|c|c|c|c|c|c|}
\hline $\begin{array}{l}\text { Sediment } \\
\text { Code }\end{array}$ & $\mathrm{pH}$ & $\begin{array}{l}\text { Conductivity } \\
{[\mathrm{mS}]}\end{array}$ & $\begin{array}{l}\text { TOC } \\
{[\%]}\end{array}$ & $\mathbf{N}[\%]$ & $\mathbf{H}[\%]$ & $\begin{array}{l}\text { AVS } \\
{[\%]}\end{array}$ & $\mathbf{P}[\%]$ & $\begin{array}{c}\text { Heavy } \\
\text { Metals } \\
{[\mathrm{mg} / \mathrm{kg}]}\end{array}$ & $\begin{array}{c}\text { PAH } \\
{[\mu \mathrm{g} / \mathrm{kg}]}\end{array}$ & $\begin{array}{c}\text { Sand [\%] } \\
(0.063-1 \\
\text { mm })\end{array}$ & $\begin{array}{c}\text { Silt [\%] } \\
(0.063-0.002 \\
\text { mm) }\end{array}$ & $\begin{array}{c}\text { Clay [\%] } \\
(<0.002 \\
\text { mm })\end{array}$ & $\begin{array}{c}\text { TBT } \\
{[\mathrm{ng} / \mathrm{g}]}\end{array}$ & $\begin{array}{l}\text { TPhT } \\
{[\mathrm{ng} / \mathrm{g}]}\end{array}$ \\
\hline S1 & 7.0 & 0.90 & 7.07 & 0.53 & 1.05 & 0.12 & 0.208 & 2399 & 9423 & 35 & 62 & 3 & 3296 & $<5$ \\
\hline S2 & 6.9 & 1.13 & 6.53 & 0.6 & 1.16 & 0.4 & 0.302 & 2497 & 9828 & 27 & 70 & 3 & 3884 & $<5$ \\
\hline S3 & 6.9 & 1.00 & 2.41 & 0.24 & 0.49 & 0.08 & 0.152 & 1213 & 2247 & 51 & 46 & 3 & 142 & 90 \\
\hline S4 & 6.7 & 0.95 & 8.81 & 0.66 & 1.24 & 0.35 & 0.297 & 2804 & 9625 & 30 & 67 & 3 & 1016 & $<5$ \\
\hline S5 & 6.7 & 0.74 & 8.37 & 0.83 & 1.4 & 0.16 & 0.399 & 3123 & no data & 21 & 75 & 4 & 345 & $<5$ \\
\hline S6 & 6.6 & 8.00 & 7.83 & 1.04 & 1.38 & 0.44 & 0.137 & 1920 & 2019.4 & 35 & 63 & 2 & 213 & $<5$ \\
\hline S7 & 6.9 & 1.02 & 15.4 & 1.37 & 2.21 & 0.9 & 0.213 & 2814 & 73595 & 24 & 74 & 3 & 220 & $<5$ \\
\hline S8 & 6.7 & 1.07 & 7.67 & 0.75 & 1.42 & 0.38 & 0.794 & 3318 & no data & 34 & 63 & 3 & 750 & $<5$ \\
\hline S9 & 7.1 & 0.88 & 9.13 & 0.91 & 1.43 & 0.1 & 0.136 & 1704 & no data & 32 & 66 & 3 & 193 & $<5$ \\
\hline S10 & 6.8 & 1.15 & 7.57 & 0.82 & 1.51 & 0.27 & 0.385 & 3710 & no data & 14 & 82 & 4 & 5263 & 9 \\
\hline
\end{tabular}




\section{Materials and Methods}

\subsection{Reagents}

Pure standards of tributyltin chloride TBT (96\%), triphenyltin chloride TPhT (95\%) and internal standard deuterated tributyltin chloride-d27 TBT-d27 (96\%) were purchased from Sigma Aldrich (St. Louis, MO, USA). HPLC gradient-grade methanol, acetonitrile and formic acid 98\% were purchased from Merck (Darmstadt, Germany). Quechers salts: Magnesium sulphate, sodium chloride, sodium acetate, ammonium acetate were purchased from Chempur (Piekary Ślaskie, Poland), trisodium citrate was purchased from Avantor (Gliwice, Poland) and disodium citrate was purchased from Acros Organics (Morris Plains, NJ, US). Sorbents, silica functionalized with primary-secondary amine (PSA) and octadecyl groups were purchased from Agilent Technologies (Santa Clara, CA, USA). Certificated Reference Material BCR ${ }^{\circledR} 646$ was purchased from Merck (Darmstadt Germany). Ultrapure water was obtained from a Millipore water purification system (MiliQ, Billerica, MA, US) equipped with UV-lamp (resistivity of $18.2 \mathrm{M} \Omega . \mathrm{cm}\left(\right.$ at $25^{\circ} \mathrm{C}$ ) and a TOC value below $5 \mathrm{ppb}$ ).

\subsection{Standard Solutions}

The stock solutions of $1 \mathrm{mg} / \mathrm{mL}$ of TBT, TPhT, and TBT-d27 were prepared in methanol. The working standard solutions were prepared by dilution of the stock solution with appropriate amount of the methanol just prior the use. All stock solutions were stored at $-25^{\circ} \mathrm{C}$.

\subsection{Chromatographic Separation Conditions and Parameters of Mass Spectrometry}

Instrumental analyses were performed using Agilent 1260 Infinity (Agilent Technologies, Santa Clara, CA, USA) equipped with a degasser, autosampler and binary pump, coupled to a Hybrid Triple Quadrupole/Linear Ion trap mass spectrometer (QTRAP ${ }^{\circledR}$ 4000, AB SIEX, Framingham, MA, USA). The curtain gas, ion source gas 1 , ion source gas 2 and collision gas (all high purity nitrogen) were set at $280 \mathrm{kPa}, 380 \mathrm{kPa}, 410 \mathrm{kPa}$ and "high" instrument units, respectively. The ion spray voltage and source temperature were $5500 \mathrm{~V}$ and $600^{\circ} \mathrm{C}$, respectively. Kinetex RP-18 column (100 mm, $4.6 \mathrm{~mm}$, particle size $2.6 \mu \mathrm{m}$ ) supplied by Phenomenex (Torrance, CA, USA) was used. The column temperature was $40{ }^{\circ} \mathrm{C}$; eluent flow rate was $0.5 \mathrm{~mL} / \mathrm{min}$. The eluent was prepared from two solutions: $\mathrm{A}-0.2 \%$ formic acid in water and $\mathrm{B}-0.2 \%$ formic acid in acetonitrile. The concentration of solution $\mathrm{B}$ in eluent was $5 \%$ for $2 \mathrm{~min}$, after that, the concentration increased to $95 \%$ in $7.5 \mathrm{~min}$ and for the next $5 \mathrm{~min}$ was $95 \%$. The injection volume was $10 \mu \mathrm{L}$. The organotin compounds were analyzed in multiple reaction monitoring $(\mathrm{MRM})$ mode. Two ion transitions (precursor $\rightarrow$ product ion) for TBT and TPhT were presented in Table 5 .

Table 5. MS/MS optimized parameters: Declustering potential (DP), collision energy (CE), entrance potential (EP), and collision cell exit potential (CXP) for quantitative and qualitative product ions of examined compounds.

\begin{tabular}{ccccccccccc}
\hline Compound & $\begin{array}{c}\text { [M+H]+ } \\
\text { Ion }\end{array}$ & $\begin{array}{c}\text { Quantitative } \\
\text { Product Ion }\end{array}$ & $\begin{array}{c}\text { DP } \\
\text { [V] }\end{array}$ & $\begin{array}{c}\text { CE } \\
\text { [V] }\end{array}$ & $\begin{array}{c}\text { EP } \\
\text { [V] }\end{array}$ & $\begin{array}{c}\text { CXP } \\
\text { [V] }\end{array}$ & $\begin{array}{c}\text { Qualitative } \\
\text { Product Ion }\end{array}$ & $\begin{array}{c}\text { DP } \\
\text { [V] }\end{array}$ & $\begin{array}{c}\text { CE } \\
\text { [V] }\end{array}$ & $\begin{array}{c}\text { EP } \\
\text { [V] }\end{array}$ \\
\hline Tributyltin & 291 & 179 & 71 & 19 & 19 & 12 & 122 & 71 & 10 & 33 \\
Tributyltin & 318 & 190 & 76 & 21 & 19 & 14 & 126 & 76 & 37 & 33 \\
deuterated & & 196 & 126 & 10 & 37 & 14 & 119 & 126 & 10 & 41 \\
Triphenlyltin & 351 & & & & & & & & &
\end{tabular}

\subsection{Sample Collection and Preparation}

Sediments samples were collected from the Odra River Estuary by the use of Van Veen grab sampler. The volume of each collected sample was 3 liters. Samples were kept in $4{ }^{\circ} \mathrm{C}$ till arrival to the laboratory. Then were frozen in $-80{ }^{\circ} \mathrm{C}$, freeze-dried and stored in $-80^{\circ} \mathrm{C}$ till analysis. Before analysis the sediments were grounded in an agate mortar and sieved through $0.063 \mathrm{~mm}$ sieve. The 
blank samples of sediments used in extraction optimization and method validation were prepared by drying in a vacuum dryer for $1 \mathrm{~h}$ at $100{ }^{\circ} \mathrm{C}$ and $50 \mathrm{kPa}$ in order to remove tributyltin and triphenyltin. After that, the TBT and TPhT residues were not found in the blank samples of bottom sediments.

\subsection{Optimisation of the QuEChERS Extraction Procedure}

The choice of optimal extraction parameters contained investigation of solvent composition, QuEChERS salts, extraction time and agitation technique as well as sorbent used for clean-up of the extract. Bottom sediment collected from the Odra River Estuary was taken for method optimization. Prior to use, blank samples were spiked with TBT and TPhT and kept in $4{ }^{\circ} \mathrm{C}$ for $24 \mathrm{~h}$. The concentration of each organotin compound in sample after spiking was $2500 \mathrm{ng} / \mathrm{g}$ of solid. The effectiveness of the extraction from the sediments was compare to effectiveness of the extraction from MiliQ water solution based on (Equation (3)).

$$
\text { Extraction recovery }=A_{\text {sample }} / A_{\text {mili }} \times 100 \% \text {, }
$$

where $\mathrm{A}_{\text {sample }}$ is peak area of spiked compounds extracted from sediment and $\mathrm{A}_{\text {miliQ }}$ is peak area of spiked compounds extracted from MiliQ water solution. It was assumed that OTC compounds were completely extracted from synthetic solution of analytes prepared in MiliQ water.

\subsection{Extraction Procedure}

Sample with about $0.125 \mathrm{~g}$ of sediment was placed in $2 \mathrm{~mL}$ Eppendorf ${ }^{\circledR}$ tubes. For extraction optimization and method validation, the blank samples were spiked with TBT and TPhT and kept in $4{ }^{\circ} \mathrm{C}$ for $24 \mathrm{~h}$. As an internal standard, $25 \mu \mathrm{L}$ of deuterated tributyltin (TBT-d27) was added followed by $200 \mu \mathrm{L}$ of MiliQ water. Then the samples were vigorously shaken by the use of vortex shaker for $1 \mathrm{~min}$ and $250 \mu \mathrm{L}$ of $5 \%$ formic acid in acetonitrile was added. The samples were put in vessel with ice and $100 \mathrm{mg}$ of ammonium acetate was added. Then they were extracted by ultrasonication for $5 \mathrm{~min}$ and shaken for $15 \mathrm{~min}(1500 \mathrm{rpm})$. The samples were centrifuged for $5 \mathrm{~min}$ (relative centrifuge force was $4472 \mathrm{~g}$ ) and the supernatant was collected for farther analysis.

\subsection{Method Validation}

The method validation was performed according to the European Medicines Agency guideline. Briefly, the linearity range was selected as $1-4000 \mathrm{ng} / \mathrm{g}$ of sediment for TBT and $5-4000 \mathrm{ng} / \mathrm{g}$ of sediment for TPhT. Calibration curves were prepared in quadruplicate. Lower limit of quantification (LLOQ) was established as the concentration of TBT and TPhT, for which MS signal to noise ratio is equal or greater than 5, with precision below $20 \%$ and accuracy $\pm 20 \%$. A signal-to-noise ratio (S/N) of three was used to calculate the limit of detection (LOD). Repeatability (within-run precision) was estimated for 5 repetitions. Between-run precision was estimated for 15 repetitions. Accuracy and precision of the method was estimated for samples spiked with Quality Control (QC) concentrations equal $3 \mathrm{ng} / \mathrm{g}$ (QC1), $2500 \mathrm{ng} / \mathrm{g}$ (QC2), and $4000 \mathrm{ng} / \mathrm{g}$ (QC3) for TBT, and $15 \mathrm{ng} / \mathrm{g}$ (QC1) $2500 \mathrm{ng} / \mathrm{g}$ (QC2) and $4000 \mathrm{ng} / \mathrm{g}$ (QC3) for TPhT.

Selectivity of MS signal and carry-over of the analytical method was tested separately for tributyltin, triphenyltin and internal standard tributyltin d-27. Selectivity assessment was performed by using 6 different blank samples of sediments spiked with $1 \mathrm{ng} / \mathrm{g}$ TBT and $5 \mathrm{ng} / \mathrm{g}$ TPhT. Carry-over was assessed based on 6 blank sample solutions which were injected after injections of high concentrated (1000 ng/mL) standard solutions of TBT, TPhT, and TBT-d27.

Absolute matrix effect $\left(\mathrm{ME}_{\mathrm{A}}\right)$, relative matrix effect $\left(\mathrm{ME}_{\mathrm{R}}\right)$, and extraction recovery $(\mathrm{RE})$ was studied on 10 sediments from the Odra River Estuary differing in the content of total organic carbon (TOC) from $0.1 \%$ to $11.8 \%$. The characteristic of the sediments is presented in Appendix (Table A1). For $\mathrm{ME}_{\mathrm{A}}$ and $\mathrm{ME}_{\mathrm{R}}$ evaluation, the samples were spiked with TBT and TPhT to concentrations corresponding $2500 \mathrm{ng} / \mathrm{g}, 1000 \mathrm{ng} / \mathrm{g}, 500 \mathrm{ng} / \mathrm{g}, 100 \mathrm{ng} / \mathrm{g}$, and $50 \mathrm{ng} / \mathrm{g}$ of solid. $\mathrm{ME}_{\mathrm{A}}$ was calculated based on the slope 
of the calibration curve $(y=a x+b)$ established by calibration solutions prepared in extracts of control sediments $\left(\mathrm{a}_{\text {control }}\right)$ and the calibration curve established by calibration solutions prepared in MiliQ water $\left(\mathrm{a}_{\text {miliQ }}\right)$ (Equation (4)).

$$
M E_{A}=a_{\text {control }} / a_{\text {miliQ }} \times 100 \%,
$$

$\mathrm{ME}_{\mathrm{R}}$ was calculated for 10 sediments as coefficient variation $(\mathrm{CV} \%)$ of normalized $\mathrm{ME}_{\mathrm{A}}$ referred as a ratio of absolute matrix effect of analyte $\left(b_{\text {analyte }}\right)$ to absolute matrix effect of internal standard $\left(b_{\text {IS }}\right)$ (Equation (5)).

$$
M E_{R}=C V \%\left(b_{\text {analyte }} / b_{I S}\right),
$$

Additionally, for five samples the absolute matrix effect was also determined before and after sieving through $0.063 \mathrm{~mm}$ sieve. The extraction recovery was determined by comparing the peak areas of blank samples spiked with TBT and TPhT (1000 ng/g of solid) before and after extraction. Samples used for recovery and matrix effect were characterized by granulometry, $\mathrm{pH}$ of MiliQ water extract, conductivity of MiliQ water extract and total organic carbon (TOC), total nitrogen content $(\mathrm{N})$, total hydrogen content $(\mathrm{H})$, acid volatile sulfur (AVS), total phosphorus $(\mathrm{P})$, sum of 16 priority polycyclic aromatic hydrocarbons (PAH), and sum of heavy metals (arsenic, barium, cadmium, cobalt, chromium, copper, iron, molybdenum, nickel, mercury, manganese, lead, tin, and zinc). Heavy metals were analysed by the use of inductively coupled plasma mass spectrometry ICP-MS. Elemental analysis (N, H, S, P, and heavy metals), TOC and PAH analyses were performed in Polish Geological Institute-National Research Institute according to accredited methods (in accordance with ISO-17025). Granulometric analysis was performed at University of Szczecin (in accordance with ISO 13320). Conductivity and $\mathrm{pH}$ of MiliQ water were measured in Medical University of Warsaw.

Stability of TBT and TPhT was evaluated in various conditions using blank samples of sediments spiked with TBT and TPhT to concentration equals $3 \mathrm{ng} / \mathrm{g}$ for TBT and $15 \mathrm{ng} / \mathrm{g}$ for TPhT (at low OTC concentrations) and $4000 \mathrm{ng} / \mathrm{g}$ for TBT and TPhT (at high OTC concentrations). The stability of analyte in the matrix was tested for three cycles of freeze and thaw (samples were frozen for at least $12 \mathrm{~h}$ after thawed). Short-term stability was tested for samples kept at room temperature for $4 \mathrm{~h}$. Long-term stability was tested after storage of samples at $-25{ }^{\circ} \mathrm{C}$ for 30 days. Stability of the extract in the autosampler was tested after $24 \mathrm{~h}$ and $48 \mathrm{~h}$. Stability of working standards at concentration $10 \mu \mathrm{g} / \mathrm{mL}$ after storage at $-25^{\circ} \mathrm{C}$ for 30 days were also evaluated.

The certified reference material BCR 646 (European Commission Joint Research Centre Institute for Reference Materials and Measurements, Geel, Belgium) was used to validate the analytical method. The material consists of a dried and ground harbor bottom sediment sample with a particle size $<90$ $\mu \mathrm{m}$ and TBT and TPhT at concentration 480 and $29 \mathrm{ng} / \mathrm{g}$, respectively. Validation of the method was based on results of six repetitions of OTC determination in BCR 646.

\subsection{Real Sample Analysis}

The concentration of tributyltin and triphenyltin in ten real samples collected from the Odra River Estuary were determined with use of the new validated method. Geographical localizations of sampling sites and depths of sampling are presented in Table 6.

\subsection{Statistical Analysis}

The statistical analysis of the results was performed with the STATISTICA version 13.1 for Windows (TIBCO Software Inc.; Palo Alto, CA, USA) and Metaboanalyst 4.0. Student's t-Test was used for comparison of samples. Spearman's correlation was used to measure the relationship between parameters of the analytical method and characteristic of sediment. Principal component analysis (PCA) was used to visualize the differences between sediment samples with high and low $\mathrm{ME}_{\mathrm{A}}$ depending on their properties i.e.; $\mathrm{pH}$, granulometry, elemental analysis, $\mathrm{PAH}$. 
Table 6. Geographic coordinates, depth of sampling and localization name of sediments collected from the Szczecin Lagoon.

\begin{tabular}{|c|c|c|c|c|}
\hline \multirow{2}{*}{$\begin{array}{l}\text { Sample } \\
\text { Number }\end{array}$} & \multicolumn{2}{|c|}{ Geographic Coordinates } & \multirow{2}{*}{$\begin{array}{l}\text { Depth of Sampling Measured } \\
\text { from Water Surface [m] }\end{array}$} & \multirow{2}{*}{ Localization } \\
\hline & Latitude-N & Longitude-E & & \\
\hline $\mathrm{S} 1$ & $53^{\circ} 27.328^{\prime}$ & $14^{\circ} 35.968^{\prime}$ & 2.2 & Szczecin Shipyard \\
\hline $\mathrm{S} 2$ & $53^{\circ} 27.336^{\prime}$ & $14^{\circ} 35.434^{\prime}$ & 2.5 & Gunica River \\
\hline S3 & $53^{\circ} 26.300^{\prime}$ & $14^{\circ} 35.280^{\prime}$ & 10.3 & Elevator "Ewa" \\
\hline S4 & $53^{\circ} 27.621^{\prime}$ & $14^{\circ} 36.102^{\prime}$ & 2.2 & Swieta River \\
\hline S5 & $53^{\circ} 27.068^{\prime}$ & $14^{\circ} 36.287^{\prime}$ & 2.1 & Dabie Lake \\
\hline S6 & $53^{\circ} 54.329^{\prime}$ & $14^{\circ} 15.249^{\prime}$ & 5.6 & Piast Canal \\
\hline S7 & $53^{\circ} 33.481^{\prime}$ & $14^{\circ} 34.578^{\prime}$ & 1.9 & Larpia River- Police- \\
\hline S8 & $53^{\circ} 24.227^{\prime}$ & $14^{\circ} 32.492^{\prime}$ & 2.0 & Szczecin Harbor \\
\hline S9 & $53^{\circ} 23.895^{\prime}$ & $14^{\circ} 37.698^{\prime}$ & 5.0 & $\begin{array}{c}\text { Szczecin - Dabie } \\
\text { Marina Club }\end{array}$ \\
\hline S10 & $53^{\circ} 27.895^{\prime}$ & $14^{\circ} 35.923^{\prime}$ & 1.7 & $\begin{array}{c}\text { Szczecin- West Odra } \\
\text { River }\end{array}$ \\
\hline
\end{tabular}

\section{Conclusions}

The analytical method for the analysis of tributyltin and triphenyltin in sediments based on the combination QuEChERS extraction with LC-MS/MS technique was successfully developed and applied in pilot study TBT and TPhT pollution in bottom sediments of the Odra River Estuary, north-westernmost part of Poland. The method met acceptance all validation criteria according to guideline on bioanalytical method validation issued by European Medicines Agency. The determined concentrations of TBT and TPhT in reference material BCR 646 by the method is in good accordance with certificated concentrations. Additionally, the method is less time consuming, cheaper and more environmentally-friendly compared to widely used method ISO 23161. The time of sample preparation is significantly shorter due to simplicity of the method. The most important is also low use of organic reagents in QuEChERS extractions. In the new method only $0.25 \mathrm{~mL}$ of acetonitrile is needed, whereas ISO 23161 method requires $5-10 \mathrm{~mL}$ of hexane and $0.5-1 \mathrm{~mL}$ of highly volatile and toxic tetrahydrofuran. The use of high quantity of other substances and sodium tetraethylborate, as derivatization agent, is also needed by ISO method. Comparison of the different analytical methods is presented in Table A2

The studies have shown that clay minerals present in bottom sediments may affect negatively the sensitivity of the method, both directly and indirectly. Tributyltin and triphenyltin bound strongly to clay minerals. This may slightly decrease extraction efficiency. The indirect effect is that clay minerals accumulate large amounts of organic compounds. Those compounds may affect ionization of tin compounds in ESI source of the MS.

The results of preliminary environmental monitoring of organotin compounds indicated that the presence of those compounds is likely caused by activity of maritime industry. The presence of triphenyltin may be also caused by agriculture activity. Further studies are required to assess persistence of organotin compounds in the sediments of the Odra River Estuary. The presence of organotin compounds in the bottom sediments should be taken into consideration during environmental management of dredged bottom sediment.

Author Contributions: Conceptualization J.G.; G.N.-J.; P.D.; Methodology, J.G.; G.N.-J.; P.D.; K.M., A.S.; Validation D.K.; J.G. P.D.; Formal analysis D.K. J.G.; Investigation D.K.; K.M., A.S.; Resources J.G.; K.M., A.S. P.D.; Data Curation D.K.; K.M., A.S.; Supervision, J.G.; G.N.-J.; P.D.; K.M.; A.S.; Writing-Original Draft Preparation D.K.; J.G.; P.D.,; Writing-Review and Editing J.G.; G.N.-J.; P.D.; K.M.; A.S.; Funding Acquisition, P.D.; Project Administration P.D.; All authors have read and agreed to the published version of the manuscript.

Funding: This research was financially supported by the grant OPUS 11, from National Science Centre Poland, entitled "Occurrence of organotin compounds in bottom sediment of the Odra river estuary-environment conditions affecting presence of the compounds, mobility, their degradation products and environmental persistence", grant number UMO-2016/21/B/ST10/02391. Physicochemical characteristics of the sediments were financially supported by a grant from Polish Geological Institute-National Research Institute, grant number 61.3201.1701.00.0. 
Acknowledgments: The authors wish to thank Rafał Benedyczak, Agnieszka Strzelecka, Agata Szyduk and Urszula Rydzewska for help in sampling of bottom sediments and Ryszard Marszałek for the technical assistance during LC-MS/MS analysis. D.K. thanks for Ph.D. student stipend financially supported by Warsaw Medical University and grant OPUS 11 from National Science Centre Poland (grant number UMO-2016/21/B/ST10/02391). LC-MS/MS analyses were carried out by the use of the CePT infrastructure founded by the European Union-the European Regional Development Fund within the Operational Program “Innovative Economy" for 2007-2013 years.

Conflicts of Interest: The authors declare no conflict of interest.

\section{Appendix A}

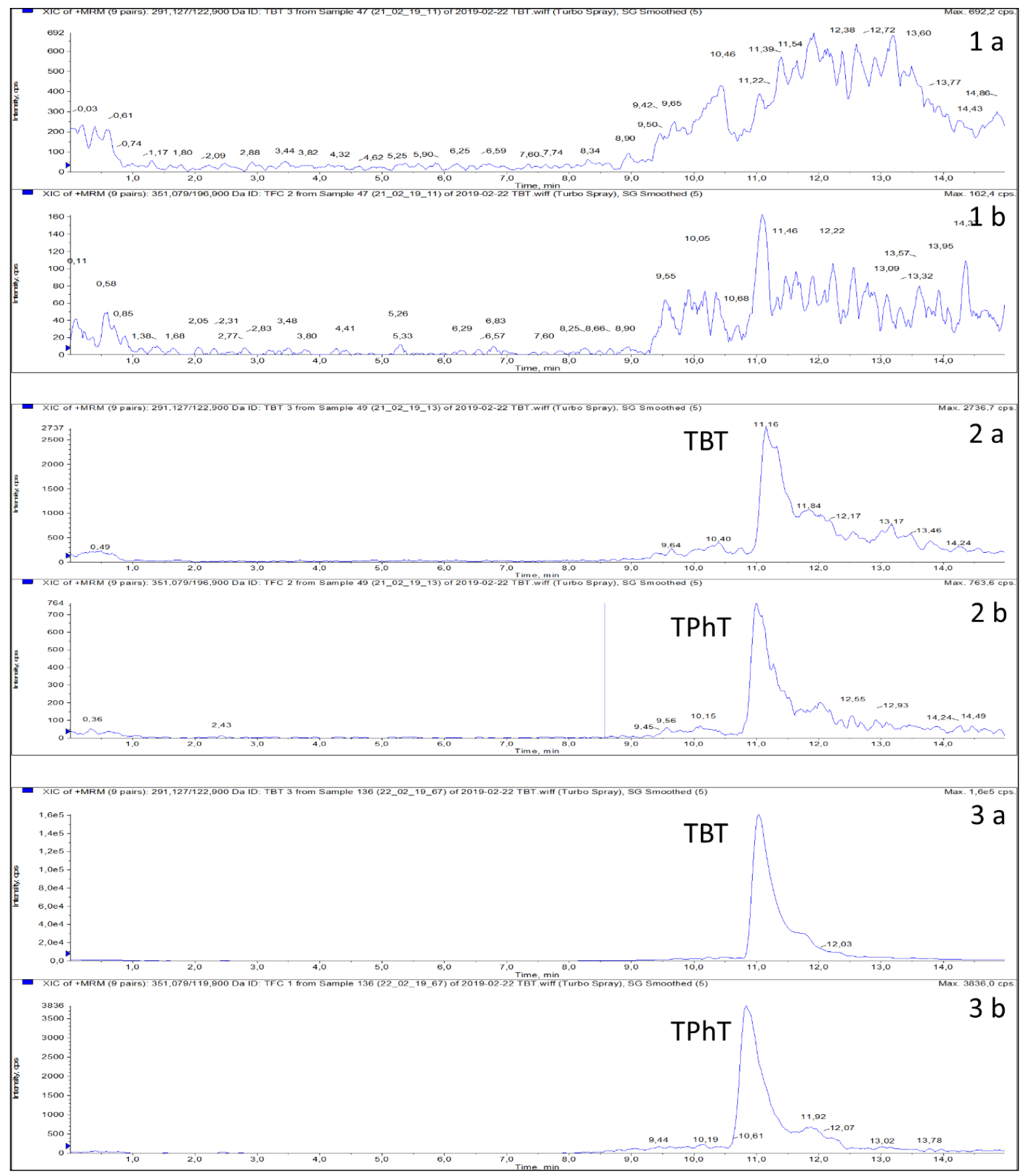

Figure A1. Chromatograms of TBT and TPhT in blank sample (1a for TBT and 1b for TPhT), lower limit of quantification (LLOQ) ( $2 a$ for TBT and $2 b$ for TPhT) and real sample (3a for TBT and $3 b$ for TPhT). 
Table A1. Localization, characteristic parameters (conductivity, $\mathrm{pH}$, total organic carbon content (TOC), total nitrogen content (N), hydrogen content (H), acid volatile sulfur (AVS), phosphorus content (P), heavy metals (arsenic, barium, cadmium, cobalt, chromium, copper, iron, molybdenum, nickel, mercury, lead, tin, zinc), sum of 16 priority polycyclic aromatic hydrocarbon $(\mathrm{PAH})$ ) and granulometry (sand fraction $(0.063-1 \mathrm{~mm})$, silt fraction $(<0.063-0.002 \mathrm{~mm})$, clay fraction $(<0.002 \mathrm{~mm})$ ) of 10 sediments used in matrix effect and recovery evaluation.

\begin{tabular}{|c|c|c|c|c|c|c|c|c|c|c|c|c|c|c|c|c|c|}
\hline $\begin{array}{l}\text { Geographic } \\
\text { coordinates }\end{array}$ & Localisation & $\begin{array}{l}\mathrm{ME}_{\mathrm{A}} \\
\mathrm{TBT} \\
{[\%]}\end{array}$ & $\begin{array}{c}\mathrm{ME}_{\mathrm{A}} \\
\mathrm{TPhT} \\
{[\%]}\end{array}$ & $\begin{array}{c}\text { RE } \\
\text { TBT } \\
{[\%]}\end{array}$ & $\begin{array}{c}\text { RE } \\
\text { TPhT } \\
{[\%]}\end{array}$ & $\mathrm{pH}$ & $\begin{array}{c}\text { Conductivity } \\
{[\mathrm{mS}]}\end{array}$ & $\begin{array}{c}\text { TOC } \\
{[\%]}\end{array}$ & $\begin{array}{c}\mathbf{N} \\
{[\%]}\end{array}$ & $\begin{array}{c}\mathbf{H} \\
{[\%]}\end{array}$ & $\begin{array}{l}\text { AVS } \\
{[\%]}\end{array}$ & $\begin{array}{c}\mathbf{P} \\
{[\mathrm{mg} / \mathrm{kg}]}\end{array}$ & $\begin{array}{c}\text { Heavy } \\
\text { Metals } \\
{[\mathrm{mg} / \mathrm{kg}]}\end{array}$ & $\begin{array}{l}\text { PAH } \\
{[\mu \mathrm{g} / \mathrm{kg}]}\end{array}$ & $\begin{array}{c}\text { Sand } \\
{[\%]}\end{array}$ & $\begin{array}{l}\text { Clay } \\
{[\%]}\end{array}$ & $\begin{array}{l}\text { Silt } \\
{[\%]}\end{array}$ \\
\hline $\begin{array}{l}\text { N 53 } 43^{\circ} 881^{\prime \prime} \\
\text { E } 14^{\circ} 35^{\prime} 224^{\prime \prime}\end{array}$ & $\begin{array}{c}\text { Skoszewska } \\
\text { Bay }\end{array}$ & 79 & 77 & 97 & 95 & 7.1 & 1.63 & 3.82 & 0.45 & 0.62 & 0.26 & 0.061 & 1808 & 1516 & 55 & 1 & 43 \\
\hline $\begin{array}{l}\text { N } 53^{\circ} 55.698^{\prime} \\
\text { E } 014^{\circ} 45.278^{\prime}\end{array}$ & $\begin{array}{l}\text { South part of } \\
\text { Cicha Bay }\end{array}$ & 80 & 63 & 92 & 88 & 7.2 & 1.92 & 11.8 & 1.34 & 1.57 & 0.61 & 0.094 & 1977 & 4460 & 38 & 1 & 61 \\
\hline $\begin{array}{l}\text { N } 53^{\circ} 51.209^{\prime} \\
\text { E } 014^{\circ} 18.107^{\prime}\end{array}$ & Karsibor & 86 & 86 & 98 & 94 & 7 & 5.01 & 1.48 & 0.41 & 0.32 & 0.06 & 0.036 & 404 & 622 & 65 & 1 & 34 \\
\hline $\begin{array}{l}\text { N } 53^{\circ} 45.638^{\prime} \\
\text { E } 014^{\circ} 17.685^{\prime}\end{array}$ & $\begin{array}{l}\text { Szczecin } \\
\text { Lagoon }\end{array}$ & 71 & 73 & 91 & 89 & 7.4 & 3.55 & 6.85 & 0.94 & 1.15 & 0.38 & 0.128 & 4183 & 4091 & 51 & 1 & 48 \\
\hline $\begin{array}{l}\text { N } 53^{\circ} 42.946^{\prime} \\
\text { E } 014^{\circ} 21.396^{\prime}\end{array}$ & $\begin{array}{l}\text { Warnolecka } \\
\text { Bay }\end{array}$ & 70 & 72 & 85 & 86 & 7.7 & 2.51 & 7.99 & 0.99 & 1.28 & 0.24 & 0.105 & 3477 & 6517 & 29 & 2 & 69 \\
\hline $\begin{array}{l}\text { N } 53^{\circ} 39.319^{\prime} \\
\text { E } 014^{\circ} 36.367^{\prime}\end{array}$ & $\begin{array}{c}\text { Roztoka } \\
\text { Odrzanska }\end{array}$ & 83 & 64 & 98 & 91 & 6.9 & 1.13 & 6.53 & 0.6 & 1.16 & 0.4 & 0.302 & 2497 & 6517 & 52 & 1 & 46 \\
\hline $\begin{array}{l}\text { N } 53^{\circ} 27.336^{\prime} \\
\text { E } 014^{\circ} 35.434^{\prime}\end{array}$ & $\begin{array}{l}\text { West Odra } \\
\text { River }\end{array}$ & 58 & 58 & 87 & 85 & 6.9 & 1.13 & 7.04 & 0.665 & 1.24 & 0.53 & 0.297 & 2594 & 9828 & 26 & 3 & 71 \\
\hline $\begin{array}{l}\mathrm{N} 53^{\circ} 26.300^{\prime} \\
\text { E } 014^{\circ} 35.280^{\prime}\end{array}$ & $\begin{array}{l}\text { Elevator } \\
\text { „Ewa” }\end{array}$ & 74 & 76 & 88 & 91 & 6.9 & 1 & 2.87 & 0.26 & 0.52 & 0.08 & 0.168 & 1300 & 2247 & 49 & 3 & 48 \\
\hline $\begin{array}{l}\text { N } 54^{\circ} 00.598^{\prime} \\
\text { E } 014^{\circ} 46.232^{\prime}\end{array}$ & $\begin{array}{l}\text { Kamienski } \\
\text { Lagoon }\end{array}$ & 92 & 92 & 106 & 99 & 7.3 & 3.15 & 0.09 & 0.03 & 0.15 & 0 & 0.008 & 51 & 3926 & 97 & 2 & 1 \\
\hline $\begin{array}{l}\text { N } 53^{\circ} 35.917^{\prime} \\
\text { E } 014^{\circ} 34.886^{\prime}\end{array}$ & Police & 68 & 62 & 90 & 87 & 6.8 & 1.273 & 0.13 & 0.03 & 0.14 & 0.03 & 0.011 & 268 & 4924 & 96 & 1 & 3 \\
\hline
\end{tabular}


Table A2. Comparison of analytical methods of tributyltin and triphenyltin determination.

\begin{tabular}{|c|c|c|c|c|c|c|}
\hline $\begin{array}{l}\text { Extraction } \\
\text { Methods }\end{array}$ & Extraction Solvents & Derivatization & Instrument & $\begin{array}{l}\text { LOD for } \\
\text { TBT [ng/g] }\end{array}$ & $\begin{array}{c}\text { LOD for } \\
\text { TPhT [ng/g] }\end{array}$ & Ref. \\
\hline QuEChERS & $\begin{array}{l}\text { acetonitrile, } \mathrm{H}_{2} \mathrm{O}, \\
\text { formic acid }\end{array}$ & No & LC-MS/MS & 0.6 & 2.4 & $\begin{array}{l}\text { This } \\
\text { work }\end{array}$ \\
\hline ASE & $\begin{array}{l}\text { Methanol, } \mathrm{H}_{2} \mathrm{O} \\
\text { acetic acid and } \\
\text { tropolone }\end{array}$ & $\mathrm{NaBT}_{4}$ & GC-FPD & 19 & 14 & [21] \\
\hline SPE & $\begin{array}{l}\text { Tetrahydrofurane, } \\
\text { hydrochloric acid, } \\
\text { tropolone, hexane }\end{array}$ & $\begin{array}{l}\text { Grignard's } \\
\text { reagent }\end{array}$ & GC-MS/MS & $0.4-1.5$ & - & [45] \\
\hline SPME & $\begin{array}{l}\text { Hydrochloric acid, } \\
\text { methanol }\end{array}$ & $\mathrm{NaBT}_{4}$ & GC-FPD & 1.7 & 20 & [46] \\
\hline MAE & $\begin{array}{l}\text { Acetic acid, tartaric } \\
\text { acid, iso-octane }\end{array}$ & $\mathrm{NaBT}_{4}$ & GC-MS & 126 & - & [47] \\
\hline
\end{tabular}

ASE—Accelerated Solvent Extraction; GC-FPD—Gas Chromatography with Flame Photometric Detector; SPE—Solid Phase Extraction; SPME—Solid Phase Microextraction; MAE-Microwace Assisted Extraction, LOD—Limit of Detection calculated based on signal-to-noise ratio $(\mathrm{S} / \mathrm{N})$ of three.

\section{References}

1. Sousa, A.; Pastorinho, M.R.; Takahashi, S.; Tanabe, S. History on organotin compounds, from snails to humans. Environ. Chem. Lett. 2014, 12, 117-137. [CrossRef]

2. Hoch, M. Organotin compounds in the environment-An overview. Appl. Geochem. 2001, 16, 719-743. [CrossRef]

3. Filipkowska, A.; Kowalewska, G. Butyltins in sediments from the Southern Baltic coastal zone: Is it still a matter of concern, 10 years after implementation of the total ban? Mar. Pollut. Bull. 2019, 146, 343-348. [CrossRef] [PubMed]

4. Matsuno-Yagi, A.; Hatefi, Y. Studies on the mechanism of oxidative phosphorylation. ATP synthesis by submitochondrial particles inhibited at F0 by venturicidin and organotin compounds. J. Biol. Chem. 1993, 268, 6168-6173. [PubMed]

5. Kotake, Y. Molecular mechanisms of environmental organotin toxicity in mammals. Biol. Pharm. Bull. 2012, 35, 1876-1880. [CrossRef] [PubMed]

6. Nakanishi, T.; Nishikawa, J.; Hiromori, Y.; Yokoyama, H.; Koyanagi, M.; Takasuga, S.; Ishizaki, J.; Watanabe, M.; Isa, S.; Utoguchi, N.; et al. Trialkyltin compounds bind retinoid $\mathrm{X}$ receptor to alter human placental endocrine functions. Mol. Endocrinol. 2005, 19, 2502-2516. [CrossRef]

7. Novelli, A.A.; Argese, E.; Tagliapietra, D.; Bettiol, C.; Ghirardini, A.V. Toxicity of tributyltin and triphenyltin to early life-stages of Paracentrotus lividus (Echinodermata: Echinoidea). Environ. Toxicol. Chem. 2002, 21, 859-864. [CrossRef]

8. Michel, P.; Averty, B. Distribution and Fate of Tributyltin in Surface and Deep Waters of the Northwestern Mediterranean. Environ. Sci. Technol. 1999, 33, 2524-2528. [CrossRef]

9. Gao, J.-M.; Wu, L.; Chen, Y.-P.; Zhou, B.; Guo, J.-S.; Zhang, K.; Ouyang, W.-J. Spatiotemporal distribution and risk assessment of organotins in the surface water of the Three Gorges Reservoir Region, China. Chemosphere 2017, 171, 405-414. [CrossRef]

10. Jones-Lepp, T.L.; Varner, K.E.; Heggem, D. Monitoring Dibutyltin and Triphenyltin in Fresh Waters and Fish in the United States Using Micro-Liquid Chromatography-Electrospray/Ion Trap Mass Spectrometry. Arch. Environ. Con. Toxicol. 2004, 46, 90-95. [CrossRef]

11. Yozukmaz, A.; Sunlu, S.F.; Sunlu, U.; Ozsuer, M. The Determination of Organotin Compounds Levels in Sediment Samples from Turkish Aegean Sea Coast. Turk. J. Fish. Aquat Sci. 2011, 11, 649-666. [CrossRef]

12. Lofrano, G.; Libralato, G.; Alfieri, A.; Carotenuto, M. Metals and tributyltin sediment contamination along the Southeastern Tyrrhenian Sea coast. Chemosphere 2016, 144, 399-407. [CrossRef]

13. Cole, R.F.; Mills, G.A.; Parker, R.; Bolam, T.; Birchenough, A.; Kröger, S.; Fones, G.R. Trends in the analysis and monitoring of organotins in the aquatic environment. Trends Environ. Anal. 2015, 8, 1-11. [CrossRef] 
14. M. Tzollas, N.; A. Zachariadis, G.; Rosenberg, E. Speciation Study of Trialkyl- and Triphenyl- Tin by Liquid Chromatography Using Ion Trap TOF Tandem MS and Atmospheric Pressure Chemical Ionization. Curr. Anal. Chem. 2013, 9, 279-287. [CrossRef]

15. Smedes, F.; De Jong, A.S.; Davies, I.M. Determination of (mono-, di- and) tributyltin in sediments. Analytical methods. J. Environ. Monit. 2000, 2, 541-549. [CrossRef] [PubMed]

16. Astruc, A.; Astruc, M.; Pinel, R.; Potin-Gautier, M. Speciation of butyltin compounds by on-line HPLC-ETAA of tropolone complexes in environmental samples. Appl. Organomet. Chem. 1992, 6, 39-47. [CrossRef]

17. Morabito, R.; Massanisso, P.; Quevauviller, P. Derivatization methods for the determination of organotin compounds in environmental samples. Trends Anal. Chem. 2000, 19, 113-119. [CrossRef]

18. Brown, K.A. Sulphur in the environment: A review. Environ. Pollut. B 1982, 3, 47-80. [CrossRef]

19. Fernández-Escobar, I.; Gibert, M.; Messeguer, À.; Bayona, J.M. Complete Elimination of Interferences in the Organotin Determination by Oxidation with Dimethyldioxirane Combined with Alumina Cleanup. Anal. Chem. 1998, 70, 3703-3707. [CrossRef]

20. Marr, I.L.; White, C.; Ristau, D.; Wardell, J.L.; Lomax, J. Interference from elemental sulphur in the determination of organotins by gas chromatography with flame photometric detection. Appl. Organomet. Chem. 1997, 11, 11-19. [CrossRef]

21. Wasik, A.; Radke, B.; Bolałek, J.; Namieśnik, J. Optimisation of pressurised liquid extraction for elimination of sulphur interferences during determination of organotin compounds in sulphur-rich sediments by gas chromatography with flame photometric detection. Chemosphere 2007, 68, 1-9. [CrossRef] [PubMed]

22. Parkinson, D.-R.; Dust, J.M. Overview of the current status of sediment chemical analysis: Trends in analytical techniques. Environ. Rev. 2010, 18, 37-59. [CrossRef]

23. Anastassiades, M.; Lehotay, S.J.; Stajnbaher, D.; Schenck, F.J. Fast and easy multiresidue method employing acetonitrile extraction/partitioning and "dispersive solid-phase extraction" for the determination of pesticide residues in produce. J. AOAC Int. 2003, 86, 412-431. [PubMed]

24. Lehotay, S.J.; Kok, A.D.; Hiemstra, M.; Bodegraven, P.V. Validation of a fast and easy method for the determination of residues from 229 pesticides in fruits and vegetables using gas and liquid chromatography and mass spectrometric detection. J. AOAC Int. 2005, 88, 595-614.

25. Perestrelo, R.; Silva, P.; Porto-Figueira, P.; Pereira, J.A.M.; Silva, C.; Medina, S.; Câmara, J.S. QuEChERS Fundamentals, relevant improvements, applications and future trends. Anal. Chim. Acta 2019, 1070, 1-28. [CrossRef]

26. Kim, L.; Lee, D.; Cho, H.-K.; Choi, S.-D. Review of the QuEChERS method for the analysis of organic pollutants: Persistent organic pollutants, polycyclic aromatic hydrocarbons, and pharmaceuticals. Trends Environ. Anal. Chem. 2019, 22, e00063. [CrossRef]

27. Soboń, A.; Szewczyk, R.; Długoński, J. Tributyltin (TBT) biodegradation induces oxidative stress of Cunninghamella echinulata. Int. Biodeter. Biodegr. 2016, 107, 92-101. [CrossRef]

28. Staniszewska, M.; Radke, B.; Namieśnik, J.; Bolałek, J. Analytical methods and problems related to the determination of organotin compounds in marine sediments. Int. J. Environ. Anal. Chem. 2008, 88, 747-774. [CrossRef]

29. González-Curbelo, M.Á.; Lehotay, S.J.; Hernández-Borges, J.; Rodríguez-Delgado, M.Á. Use of ammonium formate in QuEChERS for high-throughput analysis of pesticides in food by fast, low-pressure gas chromatography and liquid chromatography tandem mass spectrometry. J. Chromatogr. A 2014, 1358, 75-84. [CrossRef]

30. European Committee for Standardization. Foods of Plant Origin-Multimethod for the Determination of Pesticide Residues using GC- and LC-Based Analysis following Acetonitrile Extraction/Partitioning and Clean-up by Dispersive SPE - Modular QuEChERS-Method; CEN-EN 15662; European Committee for Standardization: Geneva, Switzerland, 2018.

31. Lehotay, S.J. Determination of pesticide residues in foods by acetonitrile extraction and partitioning with magnesium sulfate: Collaborative study. J. AOAC Int. 2007, 90, 485-520.

32. Hoch, M.; Alonso-Azcarate, J.; Lischick, M. Adsorption behavior of toxic tributyltin to clay-rich sediments under various environmental conditions. Environ. Toxicol. Chem. 2002, 21, 1390-1397. [CrossRef] [PubMed]

33. Bangkedphol, S.; Keenan, H.E.; Davidson, C.; Sakultantimetha, A.; Songsasen, A. The partition behavior of tributyltin and prediction of environmental fate, persistence and toxicity in aquatic environments. Chemosphere 2009, 77, 1326-1332. [CrossRef] [PubMed] 
34. González-Toledo, E.; Compañó, R.; Granados, M.; Dolors Prat, M. Detection techniques in speciation analysis of organotin compounds by liquid chromatography. Trends Anal. Chem. 2003, 22, 26-33. [CrossRef]

35. Cabrera Lda, C.; Caldas, S.S.; Prestes, O.D.; Primel, E.G.; Zanella, R. Evaluation of alternative sorbents for dispersive solid-phase extraction clean-up in the QuEChERS method for the determination of pesticide residues in rice by liquid chromatography with tandem mass spectrometry. J. Sep. Sci. 2016, 39, 1945-1954. [CrossRef]

36. Shirsath, S.R.; Sonawane, S.H.; Gogate, P.R. Intensification of extraction of natural products using ultrasonic irradiations-A review of current status. Chem. Eng. Process. 2012, 53, 10-23. [CrossRef]

37. Betz, J.M.; Brown, P.N.; Roman, M.C. Accuracy, precision, and reliability of chemical measurements in natural products research. Fitoterapia 2011, 82, 44-52. [CrossRef]

38. Thompson, M.; Ellison, S.L.R.; Wood, R. Harmonized guidelines for single-laboratory validation of methods of analysis (IUPAC Technical Report). Pure Appl. Chem. 2002, 74, 835-855. [CrossRef]

39. International Organization for Standarization. Reference Materials-Good Practice in Using Reference Materials; ISO Guide 33:2015; International Organization for Standarization: Geneva, Switzerland, 2015.

40. International Organization for Standarization. Accuracy (trueness and precision) of measurement methods and results-parts 1-6; ISO 5725-1:1994; International Organization for Standarization: Geneva, Switzerland, 1994.

41. Ouakhssase, A.; Chahid, A.; Choubbane, H.; Aitmazirt, A.; Addi, E.A. Optimization and validation of a liquid chromatography/tandem mass spectrometry (LC-MS/MS) method for the determination of aflatoxins in maize. Heliyon 2019, 5, e01565. [CrossRef]

42. Zhou, W.; Yang, S.; Wang, P.G. Matrix effects and application of matrix effect factor. Bioanalysis 2017, 9, 1839-1844. [CrossRef]

43. Filipkowska, A.; Kowalewska, G.; Pavoni, B.; Łęczyński, L. Organotin compounds in surface sediments from seaports on the Gulf of Gdańsk (southern Baltic coast). Environ. Monit. Assess. 2011, 182, 455-466. [CrossRef]

44. Filipkowska, A.; Kowalewska, G.; Pavoni, B. Organotin compounds in surface sediments of the Southern Baltic coastal zone: A study on the main factors for their accumulation and degradation. Environ. Sci. Pollut. Res. 2014, 21, 2077-2087. [CrossRef] [PubMed]

45. Cui, Z.; Qian, Y.; Ge, N.; Zhang, J.; Liu, Y.; Cao, Y. Determination of butyltin and phenyltin analogues in sea products by Grignard derivatization and gas chromatography-triple quadrupole tandem mass spectrometry. Anal. Methods 2014, 6, 9333-9339. [CrossRef]

46. Zhang, K.; Shi, J.; He, B.; Xu, W.; Li, X.; Jiang, G. Organotin compounds in surface sediments from selected fishing ports along the Chinese coast. Chin. Sci. Bull. 2013, 58, 231-237. [CrossRef]

47. Flores, M.; Bravo, M.; Pinochet, H.; Maxwell, P.; Mester, Z. Tartaric acid extraction of organotin compounds from sediment samples. Microchem. J. 2011, 98, 129-134. [CrossRef]

Sample Availability: Samples of the bottom sediments are not available from the authors.

(C) 2020 by the authors. Licensee MDPI, Basel, Switzerland. This article is an open access article distributed under the terms and conditions of the Creative Commons Attribution (CC BY) license (http://creativecommons.org/licenses/by/4.0/). 